\title{
JUDGING FAIRNESS IN CLASS ACTION SETTLEMENTS
}

\section{Catherine Piché*}

In this paper, I describe the face of modern civil justice and discuss four paradoxes which justify re-evaluating the role of the judge responsible for reviewing class action settlements, in light of modern judicial culture. I also critically evaluate the existing procedures applicable to the fairness review as well as the judicial role described in the caselaw and doctrine, before suggesting a revised, three-parted role for the reviewing judge in the class action settlement context. Ultimately, I suggest that to reach fairness of process and outcome in class action settlements, judges should remain active and creative in their inquisitorial assessment of proposed class action settlements. They should also remain conciliatory, participating in the search for solutions regarding the proposed settlement, always seeking to find the truth (and what is "just") about the proposed settlement, in the utmost respect for the rights of absent class members, the respect of their interests, and the additional consideration of the interests of the defendants and of the public.

Dans cet article, je présente l'état de la face de la justice civile moderne et je discute quatre paradoxes qui justifient une réévaluation du rôle du juge responsable de la révision et de l'approbation d'un règlement de recours collectif, à la lumière de la culture juridique moderne. Je propose aussi une évaluation critique des procédures en place s'appliquant à l'évaluation du caracters équitable de la transaction, de même que le rôle du juge décrit dans la jurisprudence et la doctrine, avant de suggérer un rôle révisé. Ce rôle modifié se décline en trois parties. Finalement, je suggère que pour atteindre l'équité de procédure et de résultat dans le cas de règlements en recours collectif, les juges devraient demeurer actifs et créatifs en enquêtant pour évaluer des règlements proposés dans les cas de recours collectifs. Ils et elles devraient aussi demeurer conciliants, participer à la recherche de solutions ayant rapport au règlement proposé, s'efforçant toujours d'en arriver à la vérité (et à ce qui est «juste») à propos du règlement proposé, dans le plus grand respect des droits des membres absents au recours collectif, le respect de leurs intérêts, et la considération additionnelle des intérêts des défendeurs et du public.

\section{INTRODUCTION}

Judges involved in class action cases have a tremendous responsibility toward class members and toward the public in general. They are asked to adjudicate the

* Faculty of Law, Université de Montréal. This paper has served as background work to my doctoral thesis, soon to be submitted at McGill University. 
rights of numerous plaintiffs; importantly, the rights of absent or unnamed ones, according to their presumed interests. Judges involved in reviewing settlements of class actions have an even more important role. They are presented with a "contract of settlement" that parties have all agreed to, and are asked to approve this contract integrally, without modifications. They must evaluate whether this contract is in the best interests of all class members - including phantom, absent or unnamed ones, in a context where there is no room for disagreement and where approval is, implicitly, strongly encouraged.

A profound revolution has taken place in civil litigation that has required that courts "reconsider and adapt old principles and structures of civil litigation which have proven unsuitable to [their] new role." ${ }^{1}$ At present, the role of the reviewing judge at the class action settlement approval stage remains unclear and unsuited to the modern class action reality. It must be revisited, in light of the changes occurring in this area of the law.

In this paper, I will first address the characteristics of modern civil justice. I will discuss four paradoxes which justify re-evaluating the role of the judge responsible for reviewing class action settlements, in light of modern judicial culture. In the second section of the paper, I will critically evaluate the existing procedures applicable to the fairness review as well as the judicial role described in the case law and doctrine, before suggesting a revised, three-part role for the judge involved with class action settlements.

Ultimately, the judicial role I herein propose is original because it encourages traditionally adversarial judges to favor an inquisitorial approach when considering proposed settlements. Instead of relying solely on counsel's arguments at the fairness hearing, it is suggested that these judges base their decisions to approve or deny proposed settlements on facts they will have actively elucidated for themselves by examination of the parties and witnesses. Furthermore, my suggested role is original because it considers the judge to be a protector of the tridimensional relationship between the class action settlement actors, as opposed to how the doctrine characterizes him, as a protector of absent class members.

\section{THE FACE OF MODERN CIVIL JUSTICE}

\section{A. A First Paradox: In The Face Of Increasingly Complex Litigation, Trials Appear To Be Vanishing}

A new litigation landscape has emerged in the last thirty years in North America. Globalization has changed civil cases, with larger numbers of parties and factual issues, more voluminous documents and complex legal issues. ${ }^{2}$ When, decades ago, Mauro Cappelletti characterized our society as a "mass production - mass consumption' civilization," with a "massification" feature that extends to the economy, social relationships, feelings and conflicts, ${ }^{3}$ he argued that the law,

\footnotetext{
1 Mauro Cappelletti, The Judicial Process in Comparative Perspective (Oxford: Oxford University Press, 1989) at 308.

2 Mauro Cappelletti, "La protection d'intérêts collectifs et de groupe dans le procès civil" (1975) 27 Rev. Int’le de Droit Comparé 571.

3 Mauro Cappelletti, "Vindicating the Public Interest Through the Courts: A Comparativist's
} 
as an instrument of social order, needed to respond to this phenomenon and rise of "meta-individual" social interests by generating "new social, collective, 'diffuse' remedies and procedures." ${ }^{4}$ Around the same time, Arthur Miller similarly characterized the then-existing legal landscape as the "Big Case Phenomenon," a "byproduct" of the mass character of contemporary American society and the complexity of its substantive regulations. ${ }^{5}$ Miller further emphasized that the "Big Case Phenomenon" applied to all litigation in general, including class action litigation. ${ }^{6}$

In the United States, this phenomenon of greater complexity of civil cases has been accompanied by larger federal district court civil caseloads. ${ }^{7}$ These caseload increases appear to have held relatively steady in very recent years: "From 2006 to 2007, total filings of civil and criminal cases in the U.S. district courts [dropped] by only 481 cases to 325,920 . [...] Civil filings in the U.S. district courts fell slightly, dropping less than 1 percent (down 2,034 cases) to 257,507." 8 And in the federal courts, the number of cases grew in civil, criminal and bankruptcy areas during the year 2009. ${ }^{9}$ In state courts, civil filings increased modestly between 1996 and 2005..$^{10}$

Canadian jurisdictions have similarly experienced their civil cases getting increasingly more complex. ${ }^{11}$ Not all of them, however, have experienced concurrent increases in civil caseloads. In fact, their experience varies according to the jurisdiction and court level:

In Alberta, statistics over the last three years show that the number of actions commenced has declined. In British Columbia, civil filings have declined from 58,189 in 1996 to

Contribution" (1975-76) 25 Buff. L. Rev. 643 at 645-6 ["Vindicating”]. Also see ibid.

4 Cappelletti, "Vindicating", ibid. at 647-48.

5 Arthur R. Miller, "Of Frankenstein Monsters and Shining Knights: Myth, Reality, and the 'Class Action Problem”" (1979) 92 Harv. L. Rev. 664 at 668. For Miller, the "traditional notion of civil litigation as merely private dispute resolution is outmoded." Ibid. at 668.

6 Ibid.

7 William F. Shughart, II \& Gokhan R. Karahan, "Study of the Determinants of Case Growth in U.S. Federal District Courts," Final Report (February 2004), online: ncjrs <http://www.ncjrs. gov/pdffiles1/nij/grants/204010.pdf> at i.

8 U.S. Courts, Press Release (March 11, 2008), online: US Courts <http://www.uscourts.gov/ News/NewsView/08-03-.11/Caseload_of_Federal_Courts_Remains_Steady_Overall.aspx> Also see U.S. Courts, Judicial Caseload Indicators (2009), online: US Courts <http://www. uscourts.gov/News/Viewer.aspx?doc=/uscourts/News/2010/docs/JudicialBusiness2009.pdf>.

9 U.S. Courts, Press Release (March 16, 2010), online: US Courts < http://www.uscourts.gov/ news/NewsView/10-03-16/Most_Federal_Court_Filings_Increase_in_2009.aspx>

10 "Examining the Work of State Courts: A National Perspective from the Court Statistics Project" (2007) online: Court Statistics Project <http://www.ncsconline.org/D_Research/csp/2006_ files/EWSC-2007WholeDocument.pdf> at 17.

11 See, e.g., Robert M. Goldschmid, "Discussion Paper: Major Themes of Civil Justice Reform” (January 2006), online: Civil Justice Reform Working Group, online: CJRWG <http://www. bcjusticereview.org/working_groups/civil_justice/cjrwg_paper_01_18_06.pdf> at 1, fn. 3 ("There is some data indicating that trials may be becoming more complex. A study by the BC Supreme Court Chief Justice Donald Brenner showed that between 1996 and 2002, while the number of cases going to trial reduced by half, average trial length doubled."). 
48,404 in 2005. In contrast, in Ontario, the 2004/05 Annual of the Court Services Division shows that there has been an increase in the number of civil cases commenced between the years 2000/01 and 2004/05 [...] In Québec, a decline in the number of civil actions (excluding family law matters, where numbers have remained relatively constant) has been observed since the 1970s. Since 2003, the number of actions appears to have stabilized. Altogether, around $40 \%$ of the public give up their right to take legal proceedings. [... $]^{12}$

In fact, even if Quebec civil filings have decreased, the length and complexity of civil cases appears to have grown in the last few years. Indeed, according to the current Quebec Superior Court's chief justice, increasingly longer hours are being spent in the courtroom. ${ }^{13}$

The existing reports on civil justice reform in North America warn that cost, delay and complexity constitute the three main problems in the administration of justice. ${ }^{14}$ The American legal system has responded to these problems by adding judges and courtrooms, and increasing judicial resources. ${ }^{15}$ It has also favoured less costly alternative dispute resolution methods such as mediation, arbitration and judicial settlement conferences, and has encouraged the judicial management of cases. ${ }^{16}$ The Canadian system has also sought to reform civil procedure through a Canadian Bar Association report entitled Systems of Civil Justice Task Force. ${ }^{17}$ This report enquires into the state of civil justice systems

12 Margaret A. Shone, "Into the Future: Civil Justice Reform in Canada - 1996 to 2006 and Beyond" (December 2006) online: Canadian Forum on Civil Justice <http://cfcj-fcjc.org/ docs/2006/shone-final-en.pdf.>. For more precise legal statistics from Quebec, see Report from Hubert Reid dated January 31, 2008, online: Wilson \& Lafleur <http://www.wilsonlafleur. com/wilsonlafleur/wl-images/cat/Memoire.pdf> (in which he reflects that since 1977, the number of cases filed in Quebec courts has declined by 55\%).

13 Chief Justice François Rolland, "Address" (opening ceremony address, delivered at the Faculty of Law, Université de Montréal, September 1, 2009) [unpublished]. In his address, Chief Justice Rolland indicated that the number of hours spent in the courtroom for audiences has grown by $10 \%$ in the last few years. This, of course, may also be the result of an inadequate administration of civil cases or caseloads by the parties and/or the courts. In the end, it is difficult to discuss judicial statistics and trends in Canada because the data available for analysis is generally nonexistent, scarce or outdated.

14 See, notably, the Québec Ministère de la Justice Report entitled "Une nouvelle culture judiciaire" (July 2001), online : Justice Quebec <http://www.justice.gouv.qc.ca/francais/publications/ rapports/pdf/crpc/crpc-rap2-intr.pdfs.

15 Ibid.

16 Stephen B. Burbank \& Linda J. Silberman, "Civil Procedure Reform in Comparative Context: The United States of America” (1997) 45:4 Amer. J. Comp. L. 675 at $678 \mathrm{f}$.

17 See Canadian Bar Association, Task Force on Systems of Civil Justice, Report of the Task Force on Systems of Civil Justice (Toronto: Canadian Bar Association, 1996). This Report was the first national survey of case management in Canada. It built on the work done by the Ontario Joint Committee on Court Reform, in Case Management and Case Flow (Ontario) (Toronto: The Ontario Joint Committee on Court Reform, 1989), and the Ontario Civil Justice Review, Civil Justice Review: First Report (Toronto: Ontario Civil Justice Review, 1995) and Ontario Civil Justice Review, Civil Justice Review: Supplemental and Final Report (Toronto: Ontario Civil Justice Review, 1996) [Ontario Civil Justice Review]. See, also Ontario Civil Justice Reform 
across Canada and develops strategies and mechanisms to assist in the continued modernization and improvement of the system. ${ }^{18}$

Hence, the first paradox of modern North American civil justice is that with the tendency to have more complex civil cases, greater numbers of civil filings ${ }^{19}$ and problematic judicial administrations due to heavy and complex caseloads, we have seen, surprisingly, a noteworthy decline in trial rates. Claiming a decline in trial rates may appear contradictory when considering that the increasing complexity of civil cases is in part evaluated by the number of days spent in court. The claim is supported by the fact that cases are longer in duration because the law is more complex, and trials appear to, by and large, have been replaced by out of court settlements.

This phenomenon, generally referred to as the "Vanishing Trial," ${ }^{20}$ raises fundamental questions about the nature of civil justice, its new culture, and the underlying changes it is undergoing. Principally, why are increasingly more complex and interesting cases willingly cut short of adjudication and settled out of court? It certainly is primarily because of the cost, complexity and delay in civil justice, and because parties want to maintain a form of control of their cases, resorting to other forms of dispute resolution mechanisms. But it could also be because judges are today asked to set aside their traditional role as adjudicators to include more managerial responsibilities, and coincidentally they take on a greater role encouraging settlements, ${ }^{21}$ which will be the subject of my second noted paradox, addressed below.

Legal processes have generally evolved to become more informative, conciliatory and negotiative. ${ }^{22}$ But how will this move away from adjudication ultimately impact the development of substantive law? And more importantly, for our purposes, what has this done to the role of the judge in North America?

Project, "Summary of Findings and Recommendations," online: Government of Ontario <http://www.attorneygeneral.jus.gov.on.ca/english/about/pubs/cjrp/CJRP-Report_EN.pdf> (In Ontario, civil justice reform has notably focused on providing access to the courts and proportionality throughout the civil process, while finding ways to foster "cultural change" in litigation among the bench and bar to recognize and to better respond to problems in the system.).

18 Interestingly, the report also develops the theme that lawyers, by virtue of their special role and expertise in the civil justice system, have a responsibility and are ideally placed to make informed and constructive contributions to improving the civil justice system.

19 Statistics in the Canadian provinces' court systems are consistent with the "Vanishing Trial" Phenomenon. For instance, while the Vancouver law courts heard in 1996 over 800 civil trials, they heard a mere 393 civil trial six years later, in 2002. See: British Columbia Justice Review Task Force, "Green Paper: The Foundations of Civil Justice Reform," (21 September 2004) [unpublished] 1; available online: Government of B.C. <http://www.bcjusticereview.org/ working_groups/civil_justice/green_paper_09_21_04.pdf>.

20 The expression "vanishing trial” originates from Marc Galanter, in "The Vanishing Trial: An Examination of Trials and Related Matters in Federal and State Courts (2004) 1 Journal of Empirical Legal Studies 459 ["Vanishing Trial"]. In a later article focusing on Federal court litigation trends (especially in a class action, mass claims resolution facilities and mandatory ADR processes context), Galanter reiterates his conclusion of declining trial rates. See, e.g., Marc Galanter, "A World Without Trials?” (2006) J. Disp. Resol. 7 [“World Without”].

21 Galanter, "Vanishing Trial," ibid. at 515-31.

22 Galanter, "World Without," supra note 20 at 23-33. 


\section{B. A Second Paradox: Our Modern Judge Is "Hands-On," Involved And Managerial, But Still Prefers To Settle}

In the modern reality of civil justice lies a second paradox. Our judges are simultaneously more involved in the organization and structure of litigation, and less involved in the litigation, clearly preferring to settle civil cases.

Today's judges administer caseloads that are overflowing with ever-complex and lengthy cases. This new litigation reality has required that the classical figure of the judge presiding over a trial be replaced by the figure of a managerial judge busy organizing the case. ${ }^{23}$ Hence, the modern, North American, judge is an active manager of cases, who conducts court business with great judicial efficiency. This judge administers civil cases from filing through disposition, seeking to achieve just, rapid, and inexpensive disposition.

In fact, this critical change in the role of judges before and after adjudication was observed twenty-five years ago by Yale Professor Judith Resnik, who then noted that these judges had become "managerial judges," supervising case preparation and monitoring case progression until completion, and deeply involved in shaping the litigation and its outcomes. ${ }^{24}$ She explained that these judges were now asking parties to prepare litigation plans, holding pre-trial conferences and scheduling orders and setting dates for trials. They were also described as meeting with parties in chambers to encourage agreements on factual and legal issues and, ultimately, settlement. ${ }^{25}$ According to Resnik, these judges had become "mediators, negotiators, and planners - as well as adjudicators." 26

Today, case management is widely recognized, as significant aspects of it are written into the U.S. Federal Rules ${ }^{27}$ and in the fourth and most recent Manual for Complex Litigation. ${ }^{28}$ In Canada, the Federal Court and most Canadian jurisdictions similarly adopted new legislation aimed at judicially managing cases, where ongoing supervision or intervention is required. The Federal Court Rules provide that all cases before the Federal Court of Canada be subject to court management. ${ }^{29}$

23 Chad M. Oldfather, "Judges as Humans: Interdisciplinary Research and the Problems of Institutional Design” (2007) Hofstra L. Rev. 125 at 130 ["Judges as Humans"]; Galanter, "Vanishing Trial," supra note 20. Also see Judith Resnik, "Managerial Judges” (1982) 96 Harv. L. Rev. 374 ["Managerial Judges”].

24 At trial, Resnik indicated that the traditional adversarial model would still predominate. See Resnik, ibid. at 377-78, 386, 403, where she describes managerial judging as a pre and post-trial phenomenon.

25 Ibid. at 377-79.

26 Ibid. at 377-79. Resnik explains at page 378 that "Judges have described their new tasks as 'case management' - hence my term 'managerial judges." On this "managerial judging” approach, also see Robert F. Peckham, "The Federal Judge as a Case Manager: The New Role in Guiding a Case from Trial to Disposition” (1981) 69 Cal. L. Rev. 779; Hon. Hubert L. Will, "The Role of the Judge in the Settlement Process"(1976) 75 F.R.D. 203.

27 See, e.g., U.S. Federal Rule of Civil Procedure 16(b).

28 Federal Judicial Center, Manual for Complex Litigation, $4^{\text {th }}$ ed. (Washington: Federal Judicial Center, 2004) at 243 (In the class action context, "[b]ecause the stakes and scope of [...] can be great, class actions often require closer judicial oversight and more active judicial management than other types of litigation.") [“Manual'].

29 Federal Court Rules, SOR/98-106, rules 380-99. The Rules provide three case management tools: (1) status reviews, which are hearings convened by the Court when parties fail to reach 
In the principally civil law province of Quebec, the 2002 civil procedure law reform similarly gave courts greater general case management powers ${ }^{30}$ and specific case management powers. ${ }^{31}$ Class actions, for instance, will be specially managed in Quebec from beginning to end, with one single judge assigned to oversee the case. ${ }^{32}$ Interestingly, the Quebec Superior Court instigated, in January 2009, a case management pilot project in the judicial District of Longueuil, seeking to accelerate the conduct of the proceedings. ${ }^{33}$ As of August 2009, the result of this project and of the introduction of a case manager has been tremendously positive, with appearances filed more quickly and civil justice being made generally more accessible. ${ }^{34}$

In the class action context, more specifically, coordination and management are crucial, given the existence of numerous class action claims, their complexity and the generally high stakes of the case. These two functions also serve to achieve justice for the parties as quickly and inexpensively as possible, while considering "the existence of unidentified parties whose interests need to be protected; the need for administrative arrangements [...] for the giving of notice and the distribution of monetary relief; the need for procedures for the determination of sub-group issues and individual questions." 35 That is principally why most law reform commissions have recommended that class action judges assume an active role in class action case management in order to have them proceed expeditiously and efficiently. ${ }^{36}$

The American Class Action Rule 23 provides several examples of judicial powers given to coordinate party activity. In Subparagraph 23(d), for instance, the judge has broad authority to "make appropriate orders: (1) determining the course of the proceedings or prescribing measures to prevent undue repetition

specific steps within certain time limits (rules 380-82); (2) specially managed proceedings, which are cases taken out of the usual court flow to proceed according to the case managing judge's orders (rules 383-85); and (3) dispute resolution, which takes the form of conferences, mediation, neutral evaluations or mini trials (rules 386-91). The province of Ontario also has a proposed Rule 77 of the Rules of Civil Procedure which establishes civil case management, seeking to reduce unnecessary litigation delay and costs, promote early and fair settlements, as well as just determinations. This Rule structures litigation around time frames for specific events and stages of litigation, and preserves the flexibility needed to allow the parties to either settle, narrow or consolidate the issues of their case. See e.g. online: Ontario Courts <http:// www.ontariocourts.on.ca/coa/en/archives/civilrules/Rule77.pdf.>

30 Indeed, article 4.1 of the Code of Civil Procedure ("C.C.P.") provides that the Court "sees to the orderly progress of the proceeding and intervenes to ensure proper management of the case." Case management powers are described in article 151.6 C.P.C. (at trial) and 508.1 C.C.P. (on appeal).

31 Special case management is made possible by articles 151.11 and following C.C.P.

32 See articles 1003 and following C.C.P.

33 See e.g., online: Point Sud <http://www.pointsud.ca/fr/Mars-2009/Premier-bilan-du-Projetpilote-visant-a-favoriser-l-accessibilite-de-la-justice.html>.

34 Ibid.

35 Australian Law Reform Commission Report, Grouped Proceedings in the Federal Court (Report \#46, 1988) at 70 .

36 In Quebec, article 1045 C.C.P. provides that the court may "at any stage of the proceedings in a class action, prescribe measures designed to hasten their progress and to simplify the proof, if they do not prejudice a party or the members; it may also order the publication of a notice to the members when it considers it necessary for the preservation of their rights." 
or complication in the presentation of evidence or argument," and to "(5) [deal] with similar procedural matters." ${ }^{37}$ Subparagraph 23(e), in addition to providing criteria and procedures for settlement approval, includes wide discretion concerning the manner of giving notice of a proposed settlement, second opt-out rights for a (b)(3) class action settlement, and approvals to withdraw objections to proposed settlements. ${ }^{38}$ Thus, Rule 23 does specifically give class action judges management powers.

One issue that immediately comes to mind - but opens up an entirely new debate - is whether judicial management really is effective in the class action context. Does it truly reduce case duration and caseloads? Does it ensure proportionality in class action procedure? And even if it presumably enhances the productivity of the process, does it ultimately lead to fairer and more equitable results?

While the answer to these questions remains unclear, ${ }^{39}$ lawyers who have cases that are managed by a judge are naturally encouraged to be better organized, and to work faster and more efficiently, while they are under steady judicial scrutiny. ${ }^{40}$ This pressure is advantageous to litigants, who will be paying for a higher quality end product, and to society at large, who may benefit from fairer and more just results. There is also a risk, however, that lawyers involved in these case-managed cases rely on the judge for direction, or bow to judicial pressure, voluntarily or not.

Another advantage of case management is that managing judges are forced to quickly and efficiently understand the case, from the onset of litigation, and to evaluate what will be the best course to follow for the remainder of the litigation, based on often limited information. Judging early and rapidly in the litigation has its risks, however. Judges will often embrace their first impression of a yet underdeveloped case. ${ }^{41}$ They may also spend more time evaluating the structure of the litigation, as opposed to its substance and the evidence, which is to the ultimate detriment of the litigants. ${ }^{42}$

Case management may also bring potential arbitrariness or bias into judi-

37 F.R.C.P. 23(d).

38 See e.g. F.R.C.P. 23(e)(1)(B), 23(e)(3) and 23(e)(4)(B) respectively.

39 Judith Resnik has noted on this point, the lack of reliable data to support a firm conclusion that case management decreases delay, produces more dispositions, and reduces litigation costs. See: Judith Resnik, "Managerial Judges and Court Delay: Unproven Assumptions”, 23 Judges' Journal. 10 (1984) at 10. See also: Thomas D. Rowe, Jr., "Authorized Managerialism Under the Federal Rules - and the Extent of Convergence with Civil-Law Judging" (2007-08) 36 Sw. U. L. Rev. 191 at 193 ("the limited empirical evidence on managerial judging's effectiveness at reducing delay and cost, to which Professor Resnik referred, remains - despite major later efforts - fairly inconclusive.")

40 See Richard L. Marcus, "An American Reaction to the Woolf Report," in A.A.S. Zuckerman \& Ross Cranston, eds., Reform of Civil Procedure (Oxford: Clarendon Press, 1995) at 234 ["American Reaction"].

41 Donald Elliott, "Managerial Judging and the Evolution of Procedure" (1986) U. Chi. L. Rev. 306 at 328 ["Managerial Judging"].

42 See Resnik, "Managerial Judges", supra note 23, in which Resnik argues that case management inherently creates a variety of serious risks of compromising impartiality and thereby conflicts with the proper judicial role. 
cial decision-making. In a class action setting for instance, case managers both encourage the parties to settle and then give the final seal of approval to outof-court resolutions of cases. Moreover, the more ad hoc adjudication of case managers is sometimes considered unfair to the parties: "Because the rules of the managerial judging 'game' are not announced in advance and because litigants rarely receive reasoned explanations for managerial (as opposed to legal) rulings, managerial decisions may be perceived as unfair." 43

Arguably, the importance of the judge's role can become diluted by having many actors collaborating within the litigation:

\section{[...] One of the characteristics of [the] phenomenon [of case management] is that judges take a very different orientation to their work than did their predecessors, potentially view- ing it as a product of their chambers - "the work of many hands"- rather than as their own, personal product. This, in turn, results in a reduction in the judge's sense of respon- sibility for that product, and in a consequent reduction in its overall quality. ${ }^{44}$}

In the end, the true value of case management mostly depends on the type of case that is being litigated. For instance, complex mass tort class actions are the ideal cases to be case managed because of their complex legal issues, hundreds or thousands of class members, numerous lawyers, and heavy paperwork. On the contrary, routine litigation cases with "no dysfunction to cure" do not need to be case managed. ${ }^{45}$

Ultimately, for these reasons, and for many other reasons to be outlined below - principally the inadequacy of the currently stated judicial role to the class action context, the "institutional architecture of the judiciary" ${ }^{46}$ must be revisited.

Case manager judges become involved so deeply and early with the core issues of the class action litigation, and with the parties and lawyers, that theywill frequently feel that the most efficient and efficacious option for the parties is to settle. They will then raise the possibility of settlement early in the litigation. Hence the second paradox of modern civil justice: how can judges become so heavily involved with the structure and organisation of a case - in addition to its legal and factual bases - as case managers, when in the end, they choose to prefer settlement over trial? While this reasoning may not appear entirely logical, there are many reasons for choosing to encourage settlement, the least of which is the "clearing dockets function." But would it not be more efficient and just to use the resources in time and effort already invested in the litigation to push the case through to trial?

43 "Managerial Judging", supra note 41 at 328.

44 "Judges as Humans", supra note 23 at 130-31.

45 Jay Tidmarsh, "Unattainable Justice: The Form of Complex Litigation and the Limits of Power" (1991-2) 60 Geo. Wash. L. Rev. 1683 at 1807.

46 "Judges as Humans, supra note 23; also citing Owen M. Fiss, The Bureaucratization of the Judiciary (1983) 92 Yale L.J. 1442. 
Settlement promotion is one of the most important consequences of case management. ${ }^{47}$ It is a value that is deeply entrenched in North American judicial culture, albeit more so in the United States than Canada. ${ }^{48}$ Where there appears to be a reasonable prospect of settlement, judges offer to mediate or to assign the case to another judge for a settlement conference. This heightened emphasis on settlement promotion has lead to a gradual "fading away of the preparation for trial rhetoric." ${ }^{49}$ In fact, settlements have been said to produce results which are closest to the ideal of justice. A federal judge describing the process at a seminar for newly-appointed judges in 1975 indicated that "[o]ptimal justice is usually found somewhere between the polar positions of the litigants. Trial is likely to produce a polar solution, and often the jury or the judge has no choice except all or nothing. Settlement is usually the avenue that allows the more just result." 50

If we are to assume that settlements produce good and just results, and that they must be preferred over litigation, then we must also appreciate that "the judge actively [participate] in bringing them about." ${ }^{51}$ Settlements, however, are not always "good." Often, the negotiation process will be unfair to one or more of the parties. This possibility is made even more dramatic in the class action context, where hundreds or thousands of individual class members are represented by one person. In that context, settlement negotiations are often conducted with many parties not having been made aware of certain facts, allegations or of the existence of the class action itself. They are also occasionally driven by lawyers with improper or fraudulent motives. In addition, settlements are often monitored and approved by judges whose prime objective is case management, and who view a trial as evidence of a "failure" of case management. ${ }^{52}$

47 However, does the promotion of settlements actually lead to more settlements? On a larger scale, does judicial case management truly increase the number of settlements? A 1984 Report published by the American Bar Association indicated that case management did not in fact lead to settlement in a greater percentage of cases. See e.g. ABA Action Commission to Reduce Court Costs and Delay, Attacking Litigation Costs and Delay, 1984, 12, cited in R.F. Peckham, "A Judicial Response to the Cost of Litigation: Case Management, Two-Stage Discovery Planning and Alternative Dispute Resolution" (1985) 37 Rutgers L. Rev. 253. Also see: Institute for Civil Justice and published as Just, Speedy, and Inexpensive? An Evaluation of Judicial Case Management Under the Civil Justice Reform Act, by J. S. Kakalik, et al., (Santa Monica: Rand Corporation, 1996).

48 Canada's judicial culture appears to be more focused on cooperation rather than confrontation or competition. See e.g. Hugh F. Landerkin \& Andrew J. Pirie, “Judges as Mediators: What's the Problem with Judicial Dispute Resolution in Canada?” (2003) 82 Can. Bar Rev. 249 at 265-66, citing Allen Linden, "In Praise of Settlement: Towards Cooperation, Away from Confrontation" (1984) 7 Can. Community L. J. 4.

49 Marc Galanter, "The Emergence of the Judge as a Mediator in Civil Cases" (1986) 69 Judicature 257 at 261. In this article, Galanter describes the history of judicial interventions in the development of "settlement processes" in the courts, noting that while most cases are settled out of court, "in many instances the negotiations are encouraged, brokered or actively mediated by the judge" and that "this has become a respectable, even esteemed, feature of judicial work."

50 Tone, "The Role of the Judge in the Settlement Process" in Seminars for Newly Appointed United States District Judges, 1975, 57, 60, as cited in "Marcus, American Reaction, supra note 40, at 226-27.

51 Galanter, supra note 49 at 261.

52 See Edward Brunet, "Questioning the Quality of Alternative Dispute Resolution" (1987) 62 Tulane L. Rev. 1 at 50 (referring to "an attitude that a trial represents judicial failure"). 
Resulting settlements may or may not end up being inherently fair to the parties either in monetary terms, or in view of the theoretical ideals of true justice and fairness.

In sum, the direction of modern litigation appears to be stretched in two opposite directions. First, modern litigation is increasingly managed in ways that effectively take it out of the hands of the parties and place it under the courts' control. Second, modern litigation is most frequently settled, giving parties exclusive control over the litigation. Nevertheless, judicial intervention and administration are considered increasingly more important to the effective functioning of civil litigation and of the class action system particularly. The North American judicial system, traditionally characterized by party control of disputes - subject only to a loose control by the courts, is changing dramatically in most jurisdictions, as judicial activism measures and new rules regarding case management and pre-trial conferences are enacted. ${ }^{53}$ In fact, the traditional models of adjudication are blurring and being replaced by a more cooperative judicial model.

\section{A Third Paradox: The Inquisitorial and Adversary Models are Increasingly Blurred and Being Replaced by Cooperative Justice}

In the most recent decade, important changes have affected the fundamental character and characteristics of civil procedure. The traditionally employed inquisitorial and adversary models have tended to lose their importance and become blurred. In addition, the trend toward case management has implicated judicial functions similar to those used by inquisitorial judges, in a way to further confuse the traditional models. Hence, the third paradox: the two traditionally efficaciously-working models appear to have been replaced by a model that promotes cooperation and the search for solutions, rather than adverseness.

While varied meanings have been assigned to the adversary and inquisitorial models, the wide - and perhaps overstated - assumption has been to associate the inquisitorial model to civil law systems, and the adversary model to common law systems. The adversary system is a procedural system in which the parties assume the primary role of investigating the facts, defining the legal issues, presenting the evidence and essentially arguing the case. This system is founded upon party-autonomy and party-prosecution. ${ }^{54}$ "Party-autonomy" means that the parties define the subject-matter of their dispute - i.e., the substance of their action, and that they can pursue their legal rights and remedies as they so wish. ${ }^{55}$ "Party-prosecution" means that the parties have the primary responsibility to choose how they will shape and structure the litigation, and which evidence they will present to the judge for adjudication. ${ }^{56}$ They investigate, prepare, present

53 See text above, footnotes 23 and following.

54 Neil Brooks, "The Judge and the Adversary System”, in The Canadian Judiciary, Allen Linden ed., (Toronto: Osgoode Hall, 1976) 90 at 93.

55 Ibid. Also see Maximo Langer, "The Rise of Managerial Judging in International Criminal Law"(2005) 53 Am. J. Comp. L. 878 at 887; J.A. Jolowicz, "Adversarial and Inquisitorial Models of Civil Procedure" (2003) 52 Int'l \& Comp. L.Q. 281 at 289 [Jolowicz, "Adversarial”].

56 Ibid. Also see Marvin Frankel, "The Search for Truth: An Umpireal View” (1975) 123 U. Pa. L. Rev. 1031 at 1042 ("The ignorant and unprepared judge is, ideally, the properly bland 
and argue the evidence and the legal arguments, while the courts preserve their right to screen or prevent the initiation of cases that are abusive or moot. Once the case is initiated, the parties prosecute it as they wish, and the judge passively evaluates the merits of the case as it is presented. He is not free to re-evaluate or adjust the terms or substance of the dispute.

By contrast, in the inquisitorial tradition, the judge investigates, gathers and reviews the facts and evidence, while the lawyers keep an eye over what is being done. ${ }^{57} \mathrm{He}$ has the "unqualified obligation to ascertain the truth," 58 "within the limits set by the pretensions of the parties, [but] without being dependent on the conduct of the parties." ${ }^{59} \mathrm{He}$ will rely heavily on experts that he will have selected himself, and will personally conduct the examinations and cross-examinations of witnesses. ${ }^{60}$

Mirjan Damaška, in The Faces of Justice and State Authority, distinguished the adversarial and non-adversarial modes of proceeding as follows:

The adversarial mode of proceeding takes its shape from a contest or a dispute: it unfolds as an engagement of two adversaries before a relatively passive decision maker whose principal duty is to reach a verdict. The nonadversarial mode is structured as an official inquiry. Under the first system, the two adversaries take charge of most procedural action; under the second, officials perform most activities. ${ }^{61}$

By requiring the affected parties to engage actively in the adjudication of their disputes, the adversarial process empowers individuals to participate, control and shape the litigation, and ensures that the resolution of disputes is reached by a neutral, impartial and uncommitted arbiter. This process relies on the accurate and fair presentation by the parties and their lawyers of all the factual and legal information relevant to the case and to the search for truth and justice.

Within North America, civil justice is characterized by the adversarial model.

figurehead in the adversary scheme of things. Because the parties and counsel control the gathering and presentation of evidence, we have no fixed, routine, expected place for the judge's contributions.")

57 John H. Langbein, "The German Advantage in Civil Procedure” (1985) 52 U. Chi. L. Rev. 823 at 826-7.

58 Franklin Strier, "What Can the American Adversary System Learn from an Inquisitorial System of Justice?” (1992) 76 Judicature 109 at 162.

59 Jolowicz, "Adversarial", supra note 55 at 43 n. 106

60 Langbein, supra note 57 at 828-9 and 835-41. Also see Hein Kotz, "The Role of the Judge in the Court-Room: The Common Law and Civil Law Compared" (1987) Journal Of South African Law 35 at 37.

61 Mirjan R. Damaška, The Faces of Justice and State Authority: A Comparative Approach to the Legal Process (New Haven: Yale University Press, 1986) at 3. In his treatise, Damaška in part argues in favour of alternative models of judicial organisation: the coordinate and hierarchical models. In the coordinate model, "lay decision-makers in a horizontal relationship of power among themselves exercise authority. In the hierarchical model, legal professional decisionmakers whose relationships are hierarchically ordered exercise authority." In that model, the court is unitary, while in the coordinate model, the court integrates a lay organ - the jury - and a professional organ - the judge. See $i b i d$, at $16 f$. 
In the United States, civil procedure officially became an adversary system with the adoption of the Federal Rules of Civil Procedure in 1938. ${ }^{62}$ In fact, the longstanding conception of the American judge has been the neutral and stoic figure "who remains above the fray and whose primary mode of action is detached reaction." ${ }^{63}$ As superbly portrayed by Duncan Kennedy, American judges are asked to "'rise above' and 'put aside,' to 'resist' and 'transcend,' their personal interest, their instinctive or intuitive sympathies, their partisan group affiliations, and their ideological commitments. They are asked to 'submit' to something 'bigger' and 'higher' than 'themselves."' 64 This role has been affected by the advent of case management, discussed above, which has forced judges to become more active and involved in the litigation at its very onset.

In Canada's mixed legal system, ${ }^{65}$ the adversarial mode continues to dominate much of civil litigation. Adjudication in the common law provinces is viewed as requiring active parties to each seek to best present their case to passive and aloof judges. ${ }^{66}$ Interestingly, in the province of Quebec, where civil matters are regulated by the civil law tradition, civil procedure has historically been firmly influenced by the common law and its mainly adversarial model. ${ }^{67}$ Accordingly,

62 "Managerial Judges," supra note 23 at 380-2. As a preliminary note, the adjudicative process must be distinguished from the adversarial system. Adjudication is a method of settling disputes that is commonly contrasted with other methods of dispute resolution such as negotiation, conciliation, mediation. It refers to a means of resolving disputes in which some general principle or rule of law is applied to the facts that give rise to the dispute and in which the parties involved are able to participate by presenting evidence and reasoned argument. See: Brooks, supra note 54, at 91. Also see Amalia D. Kessler, "Our Inquisitorial Tradition: Equity Procedure, Due Process, and the Search for an Alternative to the Adversarial" (2005) 90 Cornell L. Rev. 1181.

63 For a depiction of this conception of the judicial role, see, e.g., Lon L. Fuller, The Forms and Limits of Adjudication (1978) 92 Harv. L. Rev. 353.

64 Duncan Kennedy, A Critique of Adjudication (Cambridge: Harvard University. Press, 1997) at 3.

65 Of course, what we mean by mixed here is the fact that all provinces and territories within Canada, excluding Quebec, follow the common law legal tradition. Quebec's legal system is a hybrid one as private law generally follows the civil law tradition, and public law generally follows the common law tradition.

66 Phillips et al. v. Ford Motor Co. of Canada Ltd. et al., [1971] 2 OR 637 (CA), where the Canadian civil justice system was described as follows: "Our mode of trial procedure is based upon the adversary system in which the contestants seek to establish through relevant supporting evidence, before an impartial trier of facts, those events or happenings which form the bases of their allegations. This procedure assumes that the litigants, assisted by their counsel, will fully and diligently present all the material facts which have evidentiary value in support of their respective positions and that these disputed facts will receive from a trial judge a dispassionate and impartial consideration in order to arrive at the truth of the matters in controversy. [...] a court must be concerned with truth, [...] but it cannot embark upon a quest for the "scientific" or "technological" truth when such an adventure does violence with the primary function of the court, which has always been to do justice, according to law."

67 Indeed, before the advent of the first codification of Quebec civil procedure, the rules of practice established by the courts incorporated many elements of common law procedure. Moreover, the first Civil Code of Civil Procedure thereafter enacted in the province on June 28, 1867 preserved this common law influence as it compiled all existing law and rules on procedure, without rationalization or reconciliation of the different and differing origins of the rules. See e.g. J.-M. Brisson, La formation d'un droit mixte: l'évolution de la procédure civile de 1774 à 
the system of presentation of a judicial case and the role of the civil judge are similarly adversarial.

Certain authors have reasoned that only an adversarial presentation will assure that judges adjudicate "correctly." ${ }^{68}$ But in response, one wonders whether the adversary system is, in fact, properly suited to today's civil justice system, where most cases settle and are rarely pleaded to the adjudicator. ${ }^{69}$

In truth, the many changes affecting civil procedure around the world have made the distinction between adversarial and inquisitorial models less relevant. ${ }^{70}$ Two noteworthy developments are the increased cooperation amongst judicial institutions and the slow convergence of certain principles of civil procedure.

The first development, judicial cooperation, is noticeable in projects such as the European Union Commission's Communication Project entitled "Towards a European E-Justice Strategy," which seeks to create a European e-justice portal that provides access to information and direct access to certain European procedures. ${ }^{71}$ In North America, judicial cooperation mostly exists in the enforcement of foreign judgments, even in the absence of international treaties to that effect. ${ }^{72}$ Cooperation is also noticeable in civil processes as they increasingly require and promote the cooperation of all actors within the litigation to reach equitable and efficient outcomes. In fact, a direct application of the cooperation model is Article 10.2 of the UNIDROIT Principles, which provides that the court's judicial management, "to the extent reasonably possible, [...] be in con-

1867 (Montréal : Éd. Thémis, 1986), at 60-1; 155-61. Also see Supreme Court of Canada case in Lac d'Amiante du Québec v. 2858-0702 Québec Inc. [2001] 2 S.C.R. 743 at paras. $28 \mathrm{f}$. ("Although Quebec civil procedure is mixed, it is nonetheless codified, written law, governed by a tradition of civil law interpretation." And later at para. 33 "civil trials in Quebec are conducted within a framework that has been influenced by the common law courts. Characteristics such as the adversarial nature of the proceeding, the roles assigned to lawyers and judges, the direct examination of witnesses before the court and, now, the use of examinations on discovery, all demonstrate how significant this contribution to the civil procedure of Quebec has been.") See also Noël Jean Mazen, "Le juge civil québécois" (Approche comparative d'un système de droit mixte) (1982) 34 :2 Revue internationale de droit comparé 375 at 403 ("le droit québécois ne respecte ni les règles d'un véritable système de common law ni celles d'un système purement civiliste. Il constitue un droit mixte qui, sans appliquer pleinement le principe du précédent, n'en manifeste pas moins un respect étonnant et parfois excessif des décisions rendues [...]"); Jean-Claude Royer, La preuve civile (Cowansville, Ed. Y. Blais : 2008) at para. 49. Finally, c.f. Yves-Marie Morissette, "Gestion d'instance, proportionnalité et preuve civile : état provisoire des questions" (2009) $50: 2$ Les Cahiers de Droit 381.

68 Jolowicz, "Adversarial", supra note 55 at $288 \mathrm{f}$.

69 Certain authors have argued that the adversarial system increases the accuracy of fact-finding because (1) the parties are motivated by self-interest and hence likely to be more diligent in presenting and critically evaluating the evidence, and (2) the adversarial model counteracts bias in decision-making. See Brooks, supra note 54 at $104 \mathrm{f}$.

70 J.A. Jolowicz, "Civil Procedure in the Common and Civil Law" in Law and Legal Culture in Comparative Perspective Guenther Doeker-Mach \& Klaus Ziegart eds. (Stuttgart: Franz Steiner Verlag, 2004), 26 at 30 [Jolowicz, "Civil Procedure"].

71 COM (2008) 329 final, 30.5.2008.

72 Carlos A. Gabuardi, "Institutional Framework for International Judicial Cooperation: Opportunities and Challenges for North America", published virtually in the Biblioteca Juridica Virtual del Instituto de Investigaciones Juridicas de la UNAM, online: Juridicas <http://info8. juridicas.unam.mx/pdf/mlawrns/cont $/ 2 / \mathrm{cmm} / \mathrm{cmm} 7$.pdf $>$ at 175 . 
sultation with the parties."73

The second development is the slow convergence of the traditional adversary model with the Continental European model - less adversarial and dominated by the actions of lawyers, and more focused on "judicial fact-gathering." ${ }^{\prime 4}$ This convergence has resulted in common sets of procedures and similarities between the judicial systems on matters such as "the assertion of jurisdiction and subjectmatter jurisdiction, specifications for a neutral adjudicator, procedure for notice to defendants, rules for formulation of claims, explication of applicable substantive law, establishing facts through proof, provision for expert testimony, etc." 75

The generalized promotion by judicial systems of ideals such as procedural efficiency may have caused this phenomenon of accelerated convergence of the adversarial and inquisitorial models. The trend toward managerial judging may be another cause, especially because certain functions of the managerial judge arguably mimic those of the inquisitorial model. ${ }^{76}$ It is true that in both models, the judge is active and controls the shape and structure of the litigation. But one can argue that the case managing judge does not primarily seek to find the truth; instead, he primarily seeks to find ways to "expedite process":

The managerial judging system conceives procedure as a device that the court, with the parties' assistance, wields to expedite process. Unlike the passive and uninformed court of the adversarial system, the managerial court gets information about the case very early in the process in order to actively pressure the parties to reach factual and legal agreements and accelerate their pre-trial investigations and trial cases. But unlike the court of the inquisitorial system that actively investigates the truth, the managerial court is active to make sure

73 UNIDROIT Principles of Transnational Procedure. Also see Article 15.4 ("An additional party has the same rights and obligations of participation and cooperation as the original parties." [emphasis added]) Also see e.g., Lord Woolf's Access to Justice Report (July 1996), see online: <http://www.dca.gov.uk/civil/final/overview.htm.> The Reform provides, in part, that "litigation will be less adversarial and more co operative (...)".

74 "German Advantage", supra note 57; Wayne Brazil, "The Adversary Character of Civil Discovery: A Critique and Proposals for Change" (1978) 31 Vand. L. Rev. 1295 at 1298-1303. See also Jolowicz, "Civil Procedure", supra note 70 at 48 (suggesting that there may eventually be a convergence of the systems, but not of procedural techniques).

75 ALI/UNIDROIT Principles and Rules of Transnational Civil Procedure, Council Draft No.1 (Nov. 16, 2001), online: American Law Institute <http://www.ali.org/ali_old/ ALIUNIDROITtrans.htm\#commentary>. For instance, the notion of a "neutral" adjudicator begins with the realization that all legal systems have rules to assure that a judge or other adjudicator should be disinterested as between the parties.

76 Rowe, supra note 39 at 203; citing, notably, Linda S. Mullenix, "Lessons from Abroad: Complexity and Convergence" (2001) 46 Vill. L. Rev. 1 at 13-4 ("Although our judges still are not fact-finders, it is difficult not to take note of the increasing managerial involvement of judges in the resolution of complex cases, often verging on functions such as fact-finding.") See also Howard M. Erichson, "Mass Tort Litigation and Inquisitorial Justice" (1998-99) 87 Geo. L. J. 1983 at 2010-11; "German Advantage", supra note 57 at 858-62 and 865-66 (arguing that managerial judging is irreconcilable with adversary theory, and viewing trend toward managerial judging as a sign of convergence with inquisitorial systems). 
that the parties do not delay proceedings. ${ }^{77}$

Furthermore, the relationship between the different actors within the litigation is conceived differently in the two traditional models of civil adjudication and in case management:

If the adversarial system conceives the relationship between the main procedural actors as a dispute between two parties before a passive umpire, while the inquisitorial system presumes an official investigation that impartial officials conduct to find the truth, the managerial judging system conceives procedure as a device that the court uses with (even involuntary) collaboration and coordination from the parties to process cases as swiftly as possible. ${ }^{78}$

Accordingly, while I recognize that there exists a certain convergence of procedure, its extent may not yet be significant. The models can be interfered with, and the roles of the actors in the litigation can be reversed in ways that challenge the true definitions and boundaries of the adversary or inquisitorial models. For instance, judges are gradually becoming more active, in part to "rein over and control" lawyers who are being afforded more powers throughout the litigation. ${ }^{79}$ And in the class action context, we are seeing an implicit reversal of the traditional roles of the court (passive) and of the parties (active), as the judge is becoming more active and involved in a more inquisitorial manner, attempting to safeguard the rights of passive class members. ${ }^{80}$

Beyond the models' suggested convergence, arising from the external influences and pressures to have efficient judicial systems and to case manage litigation, the models themselves could eventually disappear because their definition and content are in constant "flux":

In the twelfth century the dichotomy was already in use to distinguish a process that required the impetus of a private complainant to get under way (processus per accusationem) from a process that could be launched in his absence (processus per inquisitionem). [...] each label now denotes distinctive clusters of traits in shifting combinations, not infrequently conflicting with one another. Only the core meaning of the opposition remains reasonably certain. [...] Beyond this core meaning uncertainty begins. It is unclear how far the adversarial process yields to the wishes of the parties ("how passive

77 Langer, supra note 55 at 836.

78 Ibid. at 878.

79 Richard Marcus, "Reining in the American Lawyer: The New Role of American Judges" (2003) 27 Hast. Int'l \& Comp. L. Rev. 3.

80 Richard A. Nagareda, "Administering Adequacy in Class Representation" (2003) 82 Tex. L. Rev. 287 at 374. 
is the judge?") and how pervasive official control is in the inquisitorial mode ("how active the officials?). [...] Another dimension is added to the complexity by the inclination of both Anglo-American and Continental lawyers to develop native variations on the theme of adversarial and inquisitorial proceedings. ${ }^{81}$

Accordingly, we are left with two models that have traditionally worked well, but are, with the modernization of civil justice, in danger of collapsing. These models are slowly being replaced by a new model that is not only cooperative, but plural. ${ }^{82}$ In addition, this model is one in which civil processes are multifaceted, alternative dispute resolution systems widely accepted, and settlements prioritized in a way to largely replace the traditional trial on the merits. Indeed, only a minority of problems are today resolved by resort to adjudication. Civil justice actors prefer to find solutions to problems and to develop ways to prevent these problems. ${ }^{83}$ Ultimately, perhaps the traditional models will only stay useful as cultural models, legal identities, ${ }^{84}$ or as reference points to understand the role of the judge in our modern society. What remains certain is that they will remain useful to developing adequate solutions for reform.

\section{A Fourth Paradox: Traditionally Adversarial Judges are Being Forced to Adjudicate in a Non-Adversarial Class Action Settlement Context; or Why the Adversary Model Is Not Appropriate for the Class Action Settlement Review}

The role of the judge inquiring into the fairness of class action settlements is complex and conflicted. Parties to the proposed settlement have essentially "contracted to settle" 85 and are no longer adversaries. Since this settlement is mostly the work of lawyers, as opposed to class members, "[j]udicial responsibility to the class is heavy." 86 A fairness hearing is held, at which stage the parties' arguments and formal proposal to settle are presented, but since all seek the same outcome - settlement approval - neither the plaintiff nor the defendant has any motivation to challenge a finding of adequacy or an appearance of inadequate representation by counsel, for instance, or to discuss any of the potential deficiencies in the settlement. This creates an inherent conflict of interest and a true adversarial void at the hearing, aptly described by Mr. Justice Paul Perell in Smith v. National Money Mart:

81 Damaška, supra note 61 at 3-4.

82 Claude Nélisse, "Le règlement déjudiciarisé : entre la flexibilité technique et la pluralité juridique” (1992) 23 R.D.U.S. 269.

83 Marie Deschamps, "L'accès à la justice: l'affaire de chacun" (2009) 50:1 Cahiers de droit 247 at 253.

84 See e.g. H. Patrick Glenn, Legal Traditions of the World (Oxford: Oxford University Press, 2000) at 33-40; Kennedy, supra note 59.

85 See Richard A. Nagareda, Mass Torts in a World of Settlement (Chicago : Chicago. University Press, 2007).

86 Preliminary Draft of Proposed Amendments to the Federal Rules of Appellate Civil and Criminal Procedure, Fed. R. Civ. P. 23(e), advisory committee note (Aug. 1996). 
Normally, courts make determinations in the context of the dynamics of the adversary system where opposing views are heard. The theory of the adversary system is that truth and justice will emerge from the crucible of the opposing arguments and presentations of competing cases. However, for settlement and fee approvals because of the obvious conflict of interest of class counsel, the absent class members - who will be bound by the settlement - have no one to make their argument, unless a class member comes forward to raise an objection, which rarely occurs, or unless the court takes on the role of being an active advocate for the class, which the court is ill-equipped to do. ${ }^{87}$

Hence, the last paradox: the traditionally adversarial role of the judge is unsuited to the modern class action settlement review and approval context.

The role of the judge approving class action settlements and fees has been qualified by Barbara J. Rothstein \& Thomas E. Willging as the most important and challenging assignment that judges face:

Reviewing proposed settlements and awarding fees are usually the most important and challenging assignments judges face in the class action area. Unlike settlements in other types of litigation, class action settlements are not an unmitigated blessing for judges. Rule changes, precedent, recent legislation, and elemental fairness to class members direct you not to rubber-stamp negotiated settlements on the basis of a cursory review. Current rules [...] unambiguously place you in the position of safeguarding the interests of absent class members by scrutinizing settlements approved by class counsel. Be aware that the adversarial clashes usually end with the settlement. [...] Thus, you need to take independent steps to get the information that you'll undoubtedly need to review a settlement agreement. ${ }^{88}$

Many authors have argued that at the approval stage, the judge is "ill-equipped to engage in independent factual investigation of [the] issues" without an adversarial presentation of the issues. ${ }^{89}$ At the fairness hearing, the judge cannot act

87 Smith v. National Money Mart, 2010 ONSC 1334, para. 27. "Access to a Just Result: Revisiting Settlement Standards and Cy Près Distributions" (2010) 6:1 Can. Class Action Review 217253. Mr. Justice Perell, from the Ontario Superior Court of Justice, disagrees with those authors who say judges are "not up to the task." Indeed, he explains in Smith v. National Money Mart, 2010 ONSC 1334, para. 32: "I do not agree that judges are not up to the task of determining whether to approve settlements and class counsel fees, but I do agree with all the commentators that the tasks are difficult and made more difficult by the adversarial void."

88 Barbara J. Rothstein \& Thomas E. Willging, Managing Class Action Litigation: A Pocket Guide for Judges (Washington, D.C.: Federal Judicial Center, 2005) ["Pocket Guide"] at. 8.

89 Martin H. Redish, Wholesale Justice: Constitutional Democracy and the Problem of the Class 
as a passive adjudicator relying upon the parties and lawyers to argue the case and bring forth the relevant facts and law in line with the adversarial tradition.

Instead, and as will be further discussed below ${ }^{90}$, the judge must be active, forthcoming and engaged in "ascertaining ultimate verities." 91 Judicial review must be "exacting and thorough." 92 To overcome potential abuse, he or she must carefully scrutinize the proposed settlement, to determine whether it is "fair, reasonable and adequate" to the class. ${ }^{93}$

In fact, neither of the two traditional models of adjudication is perfectly suited to the class action system. Because the class action concerns absent or unnamed class members who have not expressly consented to the lawsuit, it disrupts the traditional conceptions of the judge, lawyers and parties' roles within the litigation. ${ }^{94}$ Class action judges become the protectors of class members and in doing so, often become so actively involved in class action management that they assume some of the lawyers' traditional functions - such as organization of the procedures and strategy of the case - functions that they may - or may not - be completely comfortable with.

Since settlements are properly considered to be contracts, class action settlements result from the parties' consent to a contract. While the law requires judges to give their seal of approval to such settlements, the reality is that they tend to give great deference to the parties' volition and agreement in the bargaining process. ${ }^{95}$ Indeed, there is evidence of certain settlements being approved by the courts that provided minimal compensation to class members. ${ }^{96}$ Meanwhile, this preference for settlements - and tendency to approve them - contradicts the increased complexity of class action litigation, which requires class action judges to also assume an active and involved role in facilitating these settlements.

In sum, I believe that the traditional role played by judges in the adversary model is not well suited to the contemporary class action settlement context. That role should be revisited, but how?

Action Lawsuit (Stanford.: Stanford University Press, 2009) at 216. While Redish discusses the settlement class in this extract, I believe that his reasoning similarly applies to settlements of certified class actions. Also see "Access to a Just Result: Revisiting Settlement Standards and Cy Près Distributions” (2010) 6 Can. Class Action Review 217-253, citing John Kleefeld ("Class Actions as Alternative Dispute Resolution" (2001), 39 Osgoode Hall L.J. 817.).

90 See infra Section B.

91 As opposed to being merely be engaged, in conformity with the adversarial tradition, in determining whether the "proper result [was] arrived at, having regard to the evidence before [him]”. See Kotz, supra note 60 at 37 (citing Hickman v. Peacey, 1945 AC 304 at 318).

92 Manual, supra note 28 at 309-311.

93 For standard of fairness, see infra note 100

94 H.Patrick Glenn, "Class Actions in Ontario and Quebec" (1984) 62 Can. B. Rev. 247 at 268; Redish, supra note 89.

95 John Bronsteen \& Owen Fiss, "The Class Action Rule” (2003) 78:5 Notre Dame Law Review at $1419,1447-1449$.

96 An example of such cases is given by Kahan and Silberman in Marcel Kahan \& Linda Silberman, "The Inadequate Search for 'Adequacy' in Class Actions: A Critique of Epstein v. MCA, Inc." (1998) 73 N.Y.U. L. Rev. 765 at 785-6 (where they explain that in one such settlement, class members individually recovered $\$ 4.38$ but were charged $\$ 80.00$ toward attorney fees). 


\section{REVISITING THE ROLE OF THE JUDGE AT THE CLASS ACTION SETTLEMENT APPROVAL STAGE}

The role of judges in civil litigation has greatly evolved in the last several decades, especially in light of the new managerial duties they must assume in evercomplex cases, especially in the class action and mass torts arenas. The principal challenge for judges has been to ascertain how to react to continuing societal, cultural and legal changes, which each bring challenges to their current responsibilities and judging philosophy.

Judges assigned to class action supervision and adjudication are in a difficult position. Their task is onerous, in great part because they are required to protect the interests of many different actors within the class action litigation: the class representative, objectors from the class who are opposed to the terms of the settlement, and other class members - both present and absent. They must also - indirectly - protect the interests of all persons potentially affected by the class action - including defendants - as they strive to achieve fair outcomes and promote respect for class action objectives. Because class action litigation is traditionally more complex than other kinds of litigation, it requires greater administration and management of the case; tasks that North American judges are not traditionally responsible for and not necessarily comfortable with. Meanwhile, the principal characteristics of their role are not truly defined, or, if defined, not uniformly so. In this paper's second section, I will review the current procedures for ascertaining class action settlement fairness and the role of the reviewing judge as currently described in the doctrine and caselaw. I will thereafter suggest a revisited role for the judge at this stage of class action litigation.

\section{A. The Class Action Settlement Fairness Review Procedure}

Class action settlements must be judicially approved by the courts to be rendered effective. This principle is recognized legislatively in Canada and in the United States. ${ }^{97}$ Before approving a settlement, judges must examine whether the proposed settlement is fair, reasonable and in the best interests of all who will be affected by it. ${ }^{8}$ Precisely, they are concerned with "safeguarding the interests

97 See e.g., F.R.C.P. 23(e) (U.S. FRCP 23(e) is a mandatory requirement that the class action "should not be dismissed or compromised without the approval of the court."); Section 29 Ontario Class Proceedings Act 1992, S.O. 1992, c. 6; Art. 1025 Quebec Civil Code of Procedure; Rule 334.29(1) Federal Court Rules, S.O.R./98-106. On the need for court review and approval of class settlements, see e.g., Knisley v. Network Assocs., Inc., 312 F.3d 1123,1125 (9 (th $^{\text {Cir. }}$ 2002) (the need for judicial review is justified by the possibility that "class counsel may collude with the defendants, tacitly reducing the overall settlement in return for a higher attorney fee"); L. Elizabeth Chamblee, "Unsettling Efficiency: When Non-Class Aggregation of Mass Torts Creates Second-Class Settlements" (2004) 65 La. L. Rev. 157, 159; Sylvia R. Lazos, Note, "Abuse in Plaintiff Class Action Settlements: The Need for a Guardian During Pretrial Settlement Negotiations" (1985) 84 Mich. L. Rev. 308, 316-325.

98 In the United States, this standard is codified in Rule 23(e)(1)(C). Also see e.g. Grunin v. Int'l House of Pancakes, 513 F.2d 114, 123 ( $8^{\text {th }}$ Cir. 1975) [Grunin]. In Canada, there is no equivalent statutory provision, such that courts have had to develop a similar standard for the judicial oversight of class action settlements. See e.g. Dabbs v. Sun Life Assurance [1998] O.J. No. 1598 (Gen. Div.) at paras $10 \mathrm{ff}[$ Dabbs]. 
of the absent class members through an analysis of the fairness and reasonableness of the settlement as it relates to those interests. [emphasis added]." 99 They must evaluate the proposed settlements and either approve or reject them, without modifications or formal amendments. ${ }^{100}$

The settling parties - through their counsel - correspondingly carry the burden of demonstrating that the settlement is fair, reasonable and adequate. ${ }^{101}$ Upon agreeing on the terms of a proposed settlement, parties and counsel will prepare and submit a joint stipulation of settlement outlining the terms, amount and form of compensation, and the effective date of settlement. ${ }^{102}$ This stipulation will serve to preliminarily evaluate the fairness of settlement, ${ }^{103}$ and may lead judges to request from the parties and counsel additional information relevant to evaluating the proposed settlement. ${ }^{104}$

The proposed settlement will usually be reviewed at two different hearings. ${ }^{105}$ The first hearing is the preliminary fairness hearing; where judges preliminarily evaluate the fairness of settlement. In the United States, court experts or special masters may be appointed at that stage to review the settlement terms, assemble information relevant to these terms and generally assist judges in the fairness determination. ${ }^{106}$ Despite the prohibition against reformulation of the proposed settlement, judges may then discuss areas of concern with the parties and suggest amendments to the proposed settlement, especially when they notice "hot

99 McCarthy v. Canadian Red Cross Soc. (2001), 8 CPC (5 $\left.5^{\text {th }}\right) 341$ Ontario S.C.J. at para. 16 ["McCarthy"]; Endean v. Can. Red Cross Soc. (1999), 68 BCLR (3d) 350 (S.C.) at paras. 13,14 and 18.

100 See e.g. in the U.S., Hanlon v. Chrysler Corp., 150 F.3d. 1011 at 1026 (9 $9^{\text {th }}$ Cir. 1998) ("The settlement must stand or fall in its entirety."); Jeff D. v. Andrus, 888 F.2d. 617 at 622 (9 ${ }^{\text {th }}$ Cir. 1989); and in Canada, Sawatzky v. Soc. Chirurgicale Instrumentarium Inc. (1999), 71 BCLR (3d) 51 (S.C.) at para. 20; Dabbs, supra note 98at para. 10.

101 Detroit (City of) v. Grinnell Corp., 495 F.2d 448 (2d Cir. 1974). Vitapharm Canada Ltd. v. F Hoffmann-La Roche Ltd., [2005] O.J. No. 1118, 74 O.R. (3d) 758 (S.C.) at para. 141 [Vitapharm]. See, e.g., Manual, supra note 28 at para. 21.634, at 322 (2004) (describing "fairness hearing").

102 In fact, the stipulation must include, in detail: (1) the timing of distribution; (2) the release between defendants and the class (and, if appropriate, between the various defendants); (3) the payment of notice costs; (4) opt-out and proof of claim procedures including "blow" provisions applicable where there are excessive opt-outs; (5) attorneys' fees; (6) confidentiality provisions; (7) choice of law and choice of forum clauses; (8) "no-admission" clauses; (9) contribution and indemnity provisions; (10) administration of the settlement funds; and (11) provisions concerning drafting and execution of any ancillary pleadings or documentation. See Herbert B. Newberg \& Alba Conte, Newberg on Class Actions, $3^{\text {rd }}$ ed. (Egan: Westbooks, 1992) para. 11.24, at 11-34. For an example of such a stipulation of settlement in the Canadian Nortel Class Action Settlement, see online: <http://www.nortelsecuritieslitigation.com/court_en1.php3>.

103 Kent A. Lambert, "Class Action Settlements in Louisiana” (2000-01) 61 La. L. Rev. 89 at 94. Lambert adds that the parties commonly supplement the stipulation with memoranda and supporting affidavits that discuss the background for the proposed settlement, the substantive merits of the case and any significant procedural hurdles. These memoranda and affidavits also outline why the proposed settlement is fair, reasonable and appropriate to all class members.

104 Manual, supra note 28 at 320.

$105 \mathrm{Ibid}$. at note. 976 (explaining that at the preliminary review, the court determines whether the proposed settlement is within the "range of reasonableness" and raises questions for the fairness hearing).

106 Ibid. at para. 21.632. 
button indicators," which indicate unfairness in the face of the proposed settlement. ${ }^{107}$ At this stage, judges may also raise questions regarding the proposed settlement, and eventually, require an independent review. ${ }^{108}$

Once the suggested corrections are made, and judges are satisfied that the proposed settlement is fair, reasonable and adequate, a final fairness hearing is scheduled for the purpose of obtaining final judicial approval ${ }^{109}$ Notice of the formal fairness hearing is usually given to class members, informing them that they will then be invited to present their opinion about the proposed settlement, and providing details about their right to object to the proposed settlement. ${ }^{110}$ In the American class action regime, this notice is mandatory under the Federal Rules of Civil Procedure. ${ }^{11}$

By contrast, in Canada, judicial practices vary regarding the preliminary fairness hearing. Judges will either formally approve the settlement, or refrain from saying anything about the settlement until objections have been properly heard. ${ }^{112}$ They may, however, flag "areas of concern" about the proposed settlement and require that these concerns be addressed in the final settlement agreement. ${ }^{113}$ When considering the notices of settlement, judges will focus their inquiry on whether the interests of absent class members have been adequately provided for. ${ }^{114}$

In Canadian jurisdictions except Quebec, the issuance of a notice has traditionally been left to the court's discretion. ${ }^{115}$ However, with the recent Supreme Court decision in Canada Post Corp v. Lépine, notice is now considered to be "indispensable," because it "informs members about how the judgment authorizing the class action or certifying the class proceeding affects them, about the rights - in particular the possibility of opting out of the class action - they have under the judgment, and sometimes, as here, about a settlement in the case." 116

The second hearing is the formal fairness hearing, mandatory in the United

107 Rothstein \& Willging. "Pocket Guide" supra note 88 at $15 \mathrm{f}$. Also see below, footnote 120.

108 Manual, supra note 28 at 21.632 (especially if there are "reservations about the settlement, such as unduly preferential treatment of class representatives or segments of the class, inadequate compensation or harms to the classes, the need for subclasses, or excessive compensation for attorneys. The parties then have an opportunity to resume negotiations in an effort to remove potential obstacles to court approval.")

109 See e.g. McCarthy, supra note 99 and later case McCarthy v. Can. Red Cross Soc. (2001), 8 CPC $\left(5^{\text {th }}\right) 350$ (S.C.J.) (June 22, 2001).

110 Manual, supra note 28 at para. 21.633.

111 F.R.C.P. 23(e)(1)(B) provides that the court "must direct notice in a reasonable manner to all class members who would be bound by a proposed settlement.") Also see In re Prudential Ins. Co. of Am.Sales Practice Litig., 177 FRD 216 at 230 (DNJ 1997) (the notice must inform the class of "the nature of the pending litigation, the general terms of the settlement, that complete information is available from the court files, and that any class member may appear and be heard at the fairness hearing.")

112 David I.W. Hamer, \& Elizabeth Stewart, Defending Class Actions in Canada, $2^{\text {nd }}$ ed. (Toronto: $\mathrm{CCH}, 2007)$ at 142 .

113 Ibid. at 146.

114 Ibid.

115 Quebec's Arts. 1025 and 1040 CPP and QRPSC, Rule 64. But see, notably, Ontario Class Proceedings Act, s. 29(4) and BC CPA s. 35(5) where the issuance of notice is discretionary.

116 Canada Post v. Lépine, 2009 SCC 16 at [42]. 
States ${ }^{17}$ and theoretically optional but practically prevelant in Canada, at which stage the settlement's proponents must properly demonstrate that the settlement is fair, reasonable, and adequate. At this hearing, the parties are allowed to present witnesses, experts, affidavits and declarations, and may also appear to present and argue their objections. ${ }^{118}$ If the judge notices "hot button indicators" which show unfairness on the face of settlement, counsel may be asked "hard questions" about the settlement's value to the class. ${ }^{119}$ The following elements are considered to be "hot button indicators" in the manual for Complex Litigation $4^{\text {th }}$, published by the U.S. Federal Judicial Center:

- Granting class members illusory non-monetary benefits, such as discount coupons for more of the defendants' product, while granting substantial monetary attorney fee awards;

- Imposing such strict eligibility conditions or cumbersome claims procedures that many members will be unlikely to claim benefits, particularly if the settlement provides that the unclaimed portions of the funds will revert to the defendants;

- Treating similarly situated class members differently (for example, by settling objectors' claims at significant higher rates than class members' claims);

- Releasing claims of parties who received no compensation in the settlement;

- Setting attorney fee based on a very high value ascribed to non-monetary relief awarded to the class, such as medical monitoring injunctions or coupons, or calculating the fee based on the allocated settlement funds; rather than the funds actually claimed by and distributed to class members; and

- Assessing class members for attorney fees in excess of the amount of damages awarded to each individual. ${ }^{120}$

At the hearing's conclusion, judges must be satisfied that they have been presented with a "sufficient record as to the basis and justification for the settlement," containing "specific findings as to how the settlement meets or fails to meet the statutory requirements." 121

Generally, court approval of class action settlements seeks to (1) judicially protect the interests of unnamed class members; and (2) prevent any and all forms of abuse, specifically through collusion between the private parties to the settlement, including counsel. ${ }^{122}$ Indeed, representative plaintiffs must not be al-

117 The fairness hearing has been mandatory since the December 2003 amendments, as it confirms prior practice. See e.g. F.R.C.P. 23(e)(1)(C).

118 Manual, supra note 28 at para. 21.634.

119 Rothstein \& Willging "Pocket Guide" supra note 88 at 27.

120 Manual, supra note 28 at 309-311.

121 Ibid. at para. 21.635.

122 ALRC Report, at para. 218; OLRC Report, at 788-89. See also Lachance v. Harrington, 965 
lowed to use the class action to improve their bargaining position to settle their individual claims on terms more favorably than those of other class members, that is, by seeking "sweetheart settlements." 123 Moreover, class counsel must not benefit from the settlement by obtaining minimal compensation for their clients.

To properly and adequately carry out their role and protect the rights of absent class members, judges evaluate the proposed settlement with care, and "set forth the reasoning supporting [their] conclusion with sufficient detail to make meaningful review possible; use of 'mere boilerplate' language will not suffice." ${ }^{124}$ In fact, while the burden of proof properly remains with the parties, these judges are required to make "appropriate independent factual findings of fairness," based on the case record. ${ }^{125}$

However, does the settlement's judicial approval end the court's involvement and responsibility to the parties? Must courts actually maintain their careful oversight at the implementation and administration phases of the settlement? Because the settlement fairness review mandates due consideration by judges of whether "satisfactory arrangements" have been made under the settlement agreement for the distribution of money to be paid to the class members, ${ }^{126}$ these judges should remain involved in the case until the settlement is properly administered and implemented. But the reality is different, at least in the United States, where the extent of the judicial oversight at the settlement implementation stage is left entirely to the judge's discretion. Indeed:

The extent to which judges police class actions is largely a matter of the individual judge's choice, influenced by traditional views of the attorney-client relationship and settlement as a form of private ordering. Not only will judges not do enough to review settlements, there is little incentive for continued judicial oversight in the administration phase. There is no requirement in the Federal Rules for judicial review of settlement administration. Although judges retain jurisdiction over settlements of class actions until administration is complete, whether the settlement administration will be reviewed or a final report issued is at the discretion of the individual judge or party request. This lack of uniformity is compounded by incentives for judges to approve settlements and not to maintain active oversight over their subsequent

F.Supp. 630 at 645 (E.D.Pa. 1997); Magana v. Platzer Shipyard, Inc., 74 F.R.D. 61 (S.D. Tex., 1977), at paras. 2-3. Also see Hamer \& Stewart, supra note 112 at 141.

123 Note, "Risk-Preference Asymmetries in Class Action Litigation" (2005) 119:2 Harv. L. Rev. 587 at 601 .

124 Foster v. Boise-Cascade, Inc., 420 F.Supp. 674 (S.D.Tex., 1976) at para. 3.

125 Ibid.

126 See e.g. Killough v. Canadian Red Cross Soc. (2001) 91 BCLR (3d) 309 (S.C.) at para. 24; In re GM Pick-Up Truck Fuel Tank Products Liability Litig., 55 F.3d 768 (in which coupon settlement was rejected). 
administration. [emphasis added] ${ }^{127}$

In Canada, while most judges historically did not feel required to oversee the administration of class action settlements, they have more recently begun to recognize the "obligation to oversee the settlement until all of the benefits have been distributed to the class members." ${ }^{128}$ In fact, that obligation is now codified in certain class action statutes such as the Ontario Class Proceedings Act, which provides in Section 26(7) that the Court must supervise the execution of judgments and distributions of awards under ss. 24 and 25. Nevertheless, the practice in Canada, as typically illustrated by the Ponderal-Redux Class Action Settlement, ${ }^{129}$ is for the judge to provide in the reasons for approval of the settlement, the appointment of a settlement administrator and initial claims adjudicators, to indicate that any party to the settlement or settlement administration be allowed to bring a motion for directions with respect to the implementation or interpretation of the agreement, and finally, that the named judge be the only one allowed to hear challenges brought regarding the settlement. Obviously, in less complex settlement agreements, it may not be necessary to ask the courts for approval and directions at various stages of the settlement process.

I believe that judges throughout North America should not only review the settlement's administration provisions item by item, ${ }^{130}$ but should also oversee the execution and administration of the settlement until all benefits have been distributed, to achieve fairness of process and outcome for class members and for all concerned by the class action and its settlement. This post-judgment jurisdiction is not only warranted by the circumstances and stated objectives of the class action, but permitted by the class action rules. Furthermore, it is consistent with the overriding managerial functions of the class action judge, ${ }^{131}$ with the "pro-active and continuing role of the judge in the litigation, as the class action settlement progresses to its final determination." 132

In practice, this would require judges to appoint claims administrators or special masters, and describe what their specific duties should be in the reasons for settlement approval. Among these duties could be a periodic reporting of all

127 Alexandra Lahav, "Fundamental Principles for Class Action Governance" (2003-04) 37 Ind. L. Rev. 65 at 91-2. Lahav further remarks that "neither the Rules nor most courts require the parties to report on the ultimate payout at the end of settlement administration." Ibid. at 87.

128 Baxter v. A. G. of Canada, 83 O.R. (3d) 481, at para. 47 [Baxter].

129 For a copy of all settlement documents, see $<$ http://www.ponderal-reduxsettlement.ca/national/ index.htm>.

130 See Clavel v. Productions musicales Donald K. Donald inc., J.E. 96-582 (C.S.), at 16-17 ("Il ne s'agit pas pour le tribunal d'estampiller candidement une entente intervenue. La distribution du reliquat doit être examinée à son mérite. Le tribunal doit étudier la suggestion de distribution du reliquat formulée [...] et ce, item par item.”)

131 Rachel Mulheron, The Class Action in Common Law Legal Systems: A Comparative Perspective (Portland: Hart Publishing, 2004) at 71.

132 Smith v. Canadian Tire Acceptance Ltd., 22 OR (3d) 433 (Gen. Div. 1995), at para. 42. Also see Chartier v. Meubles Léon Ltée, EYB 2006-111686 (Qc. Sup. Ct. 2006); Gibson v. Virginia Mason Medical Center, No. 05-2-02198-5-SEA (Sup. Ct., State Wash., 2007) (where court retains jurisdiction in class action settlement's implementation). 
distribution activities, as well as a more general progress report. ${ }^{133}$ Finally, one last, short hearing should probably be held at the close of the settlement's implementation by the same judge who approved the settlement to ensure the settlement's fair outcome for all class members in respect to all class action objectives.

\section{A Critical View Of The American Law Institute's Principles Of The Law Of Aggregate Litigation}

On March 28, 2006, Discussion Draft Principles of the Law of Aggregate Litigation were presented to the American Law Institute membership [Principles]. In these Principles was a chapter which dealt extensively with the settlement of aggregated cases, mostly in the class action context, discussing the major issues of existing judicial practice with regards to these settlements. The Principles primarily sought to improve the judicial oversight of class action settlements, including the "generally perfunctory preliminary-approval stage of proposed class settlements." "134 They were adopted at the 86th Annual Meeting of the American Law Institute on May 20, 2009. ${ }^{135}$

At first glance, the Principles are inspiring in their attempt to reflect recent, generally accepted changes in norms, practices and culture perceived in class action settlement approval processes, as they provide a list of clearly stated criteria of fairness with supporting explanations. ${ }^{136} \mathrm{On}$ a closer analysis, one notices that whilst the substantive standard of settlement fairness - that the proposed settlement be fair, just and reasonable - remains unchanged, these Principles have truly helped improve the process by which the fairness of class action settlements is evaluated. In fact, the goal of the Principles' chapter on class action settlements is to "ensure that settlements are not unduly impeded while, at the same time, requiring protections that facilitate the underlying fairness to the class of any settlement reached." 137

Section 3.02 of the Principles confirms the state of the law by providing that settlements of certified and proposed class actions must be approved by the court. As for precertification settlements, however, the Principles favour the approach of requiring "limited judicial oversight", a position justified by the "potential risks of precertification settlements or voluntary dismissals that occur without judicial scrutiny," and the fact that "the very requirement of court approval may deter parties from entering into problematic precertification settlements." ${ }^{138}$

Section 3.03 of the Principles outlines the hearing and review procedure for

133 Manual, supra note 28 at para. 21.661.

134 Discussion Draft, Principles of the Law of Aggregate Litigation, The American Law Institute, April 21, 2006, at p. xxviii [Draft Principles].

135 See online: American Law Institute <http://www.ali.org/index.cfm?fuseaction=meetings. annual_updates_09>. For this Paper's purposes, I will be working with the Final Draft of the Principles, which was adopted by the American Law Institute on April 1, 2009: American Law Institute, Principles of the Law: Aggregate Litigation (St. Paul, MN: American Law Institute Publishers, 2010) [Principles].

136 Reporters' notes to para. 3.01 state that the implementation of the principles will change the current law as explained in paras. 3.02-3.18. Principles, ibid.

137 Ibid. para. 3.01, Comment b.

138 Ibid. para. 3.02, Comment b. 
class settlements, confirming once again the state of the law by requiring that the court engage in a two-step process with a preliminary review and final fairness review. While Section 3.04 addresses the requirements of notice of class settlement, Subsection 3.05 (a) provides that settlement fairness will depend upon whether:

(1) The class representatives and class counsel have been and currently are adequately representing the class;

(2) The relief afforded to the class [...] is fair and reasonable given the costs, risks, probability of success and delays of trial and appeal;

(3) Class members are treated equitably (relative to each other) based on their facts and circumstances and are not disadvantaged by the settlement considered as a whole; and

(4) The settlement was negotiated at arm's length and was not the product of collusion. ${ }^{139}$

These factors already exist in the caselaw, but their merit is made clearer in the Principles, and the comments, illustrations and reporter's notes appended to them. What is interesting, among other things, is the fact that it is assumed that counsel will approve the settlement, and accordingly, there is no formal consideration of counsel's opinion. The experience of class counsel is also considered to be automatic, because otherwise the lawyer would not be an adequate representative according to Rule 23(a)(4) F.R.C.P. In addition, the presence and number of objectors is not considered probative (which suggests that they may instead be ill-informed, driven by fees or simply professional, troublemaking objectors), nor is the number of opt-outs (which then suggests that this criterion is not indicative of members liking or agreeing to the settlement). Accordingly, only the most determinative of the existing North American caselaw fairness factors are preserved.

Subsection 3.05 (b) of the Principles is also important because it makes Subsection 3.05 (a) applicable to "the class" and to "every substantial segment" of it, and evaluates fairness at these two levels instead of evaluating it strictly in relation to "the class as a whole," as provided in the currently applicable North American caselaw. It also opens up the possibility of concluding to the unfairness of settlement "for any other significant reason:"

(b) $[t]$ he court may approve a settlement only if it finds, based on the criteria in subsection (a), that the settlement would be fair to the class and to every substantial segment of the class. A negative finding on any of the criteria specified in subsections (a)(1)-(a)(4) renders the settlement unfair. A settlement may also be found to be unfair for any other significant reason that may arise from the facts and circumstances of the 
particular case. ${ }^{140}$

The unqualified expression "unfair for any other significant reason" begs the following question: unfair with respect to what, and to whom? What sort of reason is not significant enough to already be listed in Subsection 3.05(a)? Is the American Law Institute hereby referring to the other existing factors listed in the North American caselaw - the Dabbs factors, ${ }^{141}$ notably? While the answer remains unclear, the kinds of situations envisaged here are presumably highly specific ones where something in the facts or circumstances is fundamentally unfair. The red flag or "hot button" situations listed above ${ }^{142}$ are certainly cases which would be deemed "unfair for any other significant reason."

Subsection (c) is also fundamental because it rightly sets aside all presumptions into settlement fairness. Does it also set aside the preference for settlement? Probably not, as this preference also exists in non-class litigation, and as the Principles explicitly note that "[1]itigation of claims that the parties wish to settle imposes needless costs on the judicial system and the parties." ${ }^{\prime 43}$ But it is useful in warning class action parties once again that class action settlement review is a serious exercise which requires due consideration of all evidence available in light of the fairness criteria.

Finally, and importantly for this paper's purposes, the Principles embrace the idea of a shared responsibility in ensuring the fairness of the proposed settlement, by all the class members' fiduciaries:

[...] the burden of proof rests with the proponents of the settlement. The purpose of the court's inquiry is to ensure that the interests of the absent class members are adequately protected so that they may fairly be bound by the outcome of the case. As such, the responsibility for ensuring the fairness of the settlement rests with [those having a fiduciary obligation to the absent class members: ${ }^{144}$ the class representatives, class counsel and the court. [emphasis added] ${ }^{145}$

This shared responsibility to ensure fairness is justified by the need for added protection to class members in the class action context. Indeed, these members are bound by the outcome, whether they were aware of the class action's existence - and of its settlement - or not, unless they opt out. Hence, encouraging class representatives and counsel to be more aware of their responsibilities of protection toward class members is a great improvement in regard to the existing state of the law. Class representatives, who have been criticized for not adequate-

140 Ibid at para. 3.05 (b).

141 Dabbs, supra note 98.

142 See supra note 120 for the list of "hot button indicators".

143 See Principles, Comment b. to Para. 3.01, at 189.

144 The American Law Institute, Principles of the Law of Aggregate Litigation, Discussion Draft No. 2 (April 6, 2007), at 227.

145 Principles, supra note 135, para. 3.05, Comment c. 
ly fulfilling their duties of representation, ${ }^{146}$ are reminded of the fundamental role they play in the class action. And while the lawyers are already ethically bound to act in their clients' best interests, they now have a greater responsibility in that same context.

Other than a subsection on approval of settlement classes ${ }^{147}$ and one on cy près settlements ${ }^{148}$, the ALI Principles do not offer additional insight into what the judicial role should be at the settlement approval stage.

\section{The Judge's Currently Stated Role Reviewing Class Action Settlements}

Class action procedure is peculiar because it concerns class members who have no knowledge, motivation or financial resources to protect their own interests. ${ }^{149}$ When class actions are settled, because there is no true "client" to the case, the court adopts the role of a "skeptical client," critically examining the settlement terms as well as the implementation and administration procedures. ${ }^{150}$ But how must this skeptical client evaluate the abstract notion of fairness? And at what stage must it be evaluated? At the settlement negotiation stage? At the fairness hearing stage? At the settlement implementation stage? How must he or she act in the out-of-court, "in the shadow of the law"151 context of settlement?

The United States Federal Judicial Center recently published a Pocket guide for judges, in which it attempts to describe the role judges carry as skeptical clients and the method they should use to evaluate class action settlement fairness:
Current rules, particularly Rule 23, unambiguously place you in the position of safeguarding the interests of absent class members by scrutinizing settlements approved by class counsel. Be aware that adversarial clashes usually end with the settle- ment. [...] Thus, you need to take independent steps to get the information you will undoubtedly need to review a settlement agreement. [emphasis added] ${ }^{152}$

This excerpt illustrates the difficulty with the currently mandated role of the judge ascertaining the fairness of a class action settlement, a role that involves traditionally adversarial and neutral judges becoming active in obtaining additional information about proposed settlements. Judges are invited to search "elsewhere" for information that will allow them to take "an independent and hard look at the merits of the claims and defenses." ${ }^{153}$ But where is this information to be searched, and found? And how profoundly and energetically can

146 See notably: Jean Wegman Burns, "Decorative Figureheads: Eliminating Class Representatives in Class Actions," (1990) 42 Hastings L.J. 165.

147 Principles, supra note 135 at para.3.06.

148 Ibid at para. 3.07.

149 Manual, supra note 28 at para. 21.61.

$150 \mathrm{Ibid}$. (The court must "make an independent analysis of the settlement terms").

151 Expression taken from R. Mnookin and L. Kornhauser, "Bargaining in the Shadow of the Law: The Case of Divorce" (1979) 88 Yale L. J. 950 at 997.

152 Rothstein \& Willging "Pocket Guide" supra note 88 at 10.

153 Ibid. at 10-11. 
and must judges search for such information? How can these judges know what information is missing? In essence, what limits does the judicial discretion have?

There are few real answers to this list of questions. Upon a careful review of the proposed settlement and of its implementation terms, judges are directed to identify all potential sources of information about the settlement, and to use these sources to obtain additional agreements concluded amongst counsel, comments from objectors, or additional settlement terms. ${ }^{154}$ The information considered important to the settlement review is the information relevant to the settlement terms, the merits and reasons for the class members' claims, the anticipated benefits to the class, the number of claims filed by the members, and the amount of the settlement likely to be distributed to the members. ${ }^{155}$ It is to be found in agreements made in connection with the settlement, in prior individual settlements, in certification papers, or in evidence from the preliminary review hearing. ${ }^{156}$

The above-cited extract also refers to the duties of protection of absent class members by the class action judge. American courts have described the class action judge as a fiduciary of the absent class members. ${ }^{157}$ They have used trusts and estates law concepts and a language used in business relations to qualify the duty at the fairness hearing to uphold the rights of absent class members, with the "high duty of care that the law requires of fiduciaries." 158

Indeed, in Reynolds v. Beneficial National Bank, Seventh Circuit Judge Posner described the role of the trial judge involved in a class action as a "fiduciary for nonparticipating class members." 159 In that case, a class action had been brought by recipients of income tax refund anticipation loans, for failure to disclose the fact that the "rapid refunds" made to customers were, in fact, loans owned in part by H\&R Block. On appeal, Judge Posner set aside the judgement in first instance, explained that the judge's legal duty was to monitor all principalagent relationships in the class action. He added that since the "questionable antecedents" to the certification suggested a strong possibility of collusion or prejudice to absent class members, district judges needed to "exercise the highest degree of vigilance" in scrutinizing the proposed class action settlement. ${ }^{160}$

Judge Posner further held that the lower court judge who approved the settlement "primarily because he thought the prospects for the class if the litigation continued were uncertain" 161 abused his discretion. This judge "painted with too broad a brush, substituting intuition for the evidence and careful analysis

154 Ibid. at 11 .

155 Ibid. at 12 .

156 Ibid. at $12-13$.

157 See e.g. Chris Brummer, "Sharpening the Sword: Class Certification, Appellate Review, and the Role of the Fiduciary Judge in Class Action Lawsuits” (2004) 104 Colum. L. Rev. 1042. For U.S. Caselaw, see notably: Stewart v. General Motors Corp., 756 F.2d 1285 (7 $7^{\text {th }}$ Cir. 1985); Plummerv. Chemical Bank, 668 F.2d 654 at 660 (2d. Cir. 1982).

158 Reynolds v. Beneficial National Bank, 288 F. 3d 277 (7 $7^{\text {th }}$ Cir. 2002), at 280.

$159 \mathrm{Ibid}$. at 279-80. Also see In re Warner Communications Sec. Litig., 798 F.2d 35 at 37 (2 ${ }^{\text {nd }}$ Cir. 1986) ("a district court has the fiduciary responsibility of ensuring that the settlement is fair."); In re Cendant Corp. Litig., 264 F.3d 286 at 296 ( $3^{\text {rd }}$ Cir. 2001) (same).

160 Ibid. at 279, 288.

161 Ibid. at 284 . 
that a case of this magnitude, and a settlement proposal of such questionable antecedents and circumstances, required." ${ }^{162}$ According to Judge Posner, the trial judge should have been more rigorous. He ordered that the case be remanded for further deliberations. ${ }^{163}$

In a comment about the Reynolds case, Professor Chris Brummer argues that Judge Posner's statement of the judge's role as fiduciary, referred to both (1) an "affirmative obligation" to exercise "good faith effort," "even in the absence of bad faith, positive action or conduct on the part of the trial judge to exercise alertness," and (2) an exercise of due care in balancing a list of case-specific factors, to determine whether the trial judge has fully performed her duties to absent class members. ${ }^{164}$ In addition, he characterizes Judge Posner's statement of the judicial role as a "seemingly static duty of vigilance," tempered by increased judicial scrutiny when settlement negotiations raise red flags. ${ }^{165}$

The reviewing judge's judicial discretion has also been described as follows in the American case law:

Such a determination [of fairness] is committed to the sound discretion of the trial judge. Great weight is accorded to his views because he is exposed to the litigants, and their strategies, positions and proofs. He is aware of the expense and possible legal bars to success. Simply stated, he is on the firing line and can evaluate the action accordingly. ${ }^{166}$

In the Canadian common law provinces, the court's role at the settlement approval stage is considered to be one of "protector of the interests of absent class members." ${ }^{167}$ In the largest class action settlement in the history of Canada; the Indian Residential Schools Settlement, Justice Winkler of the Ontario Superior Court of Justice aptly described his role and obligations:

The court has an obligation under the Class Proceedings Act, 1992, [...] to protect the interests of the absent class members, both in determining whether the settlement meets the test for approval and in ensuring that the administration and implementation of the settlement are done in a matter that delivers the promised benefits to the class members. In seeking the approval of the court, the plaintiffs and defendants essentially seek the benefits of having the court sanction the settlement. Such approval cannot be divorced from the obligation it entails. Once the court is engaged, it cannot abdi-

162 Ibid. at 283 .

$163 \mathrm{Ibid}$. at 289.

164 Brummer, supra note 157 at 1065-66.

$165 \mathrm{Ibid}$. at 1066-67. Judge Posner also distinguished this legal duty from the more classic managerial responsibilities of public law litigation. Ibid. at 1067.

166 Grunin, supra note 98 at para. 11 ("Only upon a clear showing that the district court abused its discretion will this court intervene to set aside a judicially approved class action settlement.”)

167 Baxter, supra note 128. 
cate its responsibilities under the CPA. ${ }^{168}$

In Quebec civil law there is no equivalent to the common law notion of fiduciary relationship or duty. Courts have characterized the role of the reviewing judge in a class action settlement context as one of "protector" of absent class members, and even "ombudsman" or "ombudsperson" in certain cases. ${ }^{169}$

Upon consideration of a proposed settlement in a recent class action proceeding launched by former students of a Montreal private "all boys" school, for abuse alleged to have taken place there by former professors, the Quebec Superior Court judge interestingly noted that:

The discretion of the Court and its authority [...] cannot be fettered by agreement of the parties.

[...] the Court can and will ratify a settlement agreement only if it is in the fair and best interests of the group members, and if it does not contravene the law nor public order. As an ombudsperson, the Court must be particularly attentive to the rights, obligations and concerns of the group members, most of them unheard and imperfectly aware of the court proceedings. ${ }^{170}$ [emphasis added]

In an oft-cited extract from an article about the role of the judge in class action matters, one Quebec Superior Court judge stated:

[...] The representatives cannot act alone. They must be able to count on the judge's presence and responsibility to see to the interests of absent class members. It is as if there was a lawyer in front of the representatives.

[...]The judge must impartially supervise and control the conduct of the proceedings in order to protect the rights of absent class members. She must always keep in mind and seek to enforce the interests of absent class members, primarily, over and above the interests of the representatives. One must always remember that this representative pleads in the name of another and not for himself. The judge must, accordingly, always assure that the "absents are protected." ${ }^{171}$ [my translation]

168 Ibid. at para. 12.

169 See A.P.E.I.Q. v. Nortel Networks, EYB $2007-124196$ (C.A.) at para. 32 (referring to the role of "guardian" and "protector" of "members' rights"); Doyon v. Fédération des producteurs acéricoles du Québec, B.E. 97BE-899 (S.C.); Hotte v. Servier Canada inc., J.E. 2002-1798 (S.C.); Rouleau v. Placements Etteloc inc., J.E. 99-938 (S.C.); Brochu v. Société des loteries du Québec, J.E. 20031295 (S.C.).

170 Petitioners v. Association Selwyn House, EYB 2008-145897 (S.C.).

171 Ginette Piché, "Un premier rôle pour le juge", in Alain Prunijer \& Jacqueline Roy eds. Les recours collectifs en Ontario et au Québec, Actes de la première conférence Yves Pratte, (Montreal: Wilson \& Lafleur: 1992) 141 at 149-50. 
And in the words of Quebec Professor Pierre-Claude Lafond:

The adequate representation by the representative is appreciated not only at the stage of authorization. From the final judgment must emanate a process in which we have the assurance that the interests of absent class members were effectively expressed and appreciated by the Tribunal. The Tribunal has a mission to constantly control the representative's activities throughout the procedure, in order to guarantee the adequate character of the class members' representation, and correct it if inadequate. ${ }^{172}$ [my translation]

Hence, the reviewing judge has a tremendous responsibility given the nature of the class action and class members' frequent ignorance about the class action's existence and settlement. But with limited knowledge about the case and proposed settlement, it is unrealistic to expect him or her to engage with the substantive details of the settlement and anticipate its problem areas. Unfortunately, many judges simply end up relying on the representations made by counsel and presuming the settlement to be fair, reasonable and adequate. ${ }^{173}$

Judges are not the only ones who can and do protect class members - present or absent ones. Class action representatives too have been attributed duties of protection at common law, in light of their fiduciary relationship with class members. ${ }^{174}$ Class counsel too have been said to have duties - that some will characterize as "fiduciary" - to class members and not just to the named plaintiffs, for achieving fairness of class action settlements. ${ }^{175}$ They are expected to act as lawyers responsible for their clients' cases, but having constant regard for the interests of the class.

Indeed, "[c]ounsel, although taking instructions from the representative plaintiffs, must also ensure that those plaintiffs are properly advised, both as to their duty to the class as a whole and that the prosecution of the action must

172 Pierre-Claude Lafond, Le recours collectif comme voie d'accès à la justice pour les consommateurs, (Montréal: Themis, 1996) at 448. Also see Carruthers v. Paquette, [1993] R.J.Q. 1467 (C.S.).

173 See Christopher R. Leslie, "A Market-Based Approach to Coupon Settlements in Antitrust and Consumer Class Action Litigation,” (2002) 49 UCLA L. Rev. 991, 1055.

174 Poulin v. Ford Motor Corp. of Canada, [2008] O.J. No. 4153, para. 62 ("A representative plaintiff must have a general understanding of the class action procedure and the nature of the lawsuit in order to instruct counsel. His responsibilities to other class members are akin to that of a fiduciary. The motion judge correctly identified factors that militated against Mr. Poulin acting as the representative plaintiff.")

175 See Roger Cramton, "Individualized Justice, Mass Torts, and 'Settlement Class Actions': An Introduction" (1995) 80 Cornell L. Rev. 811 at 822 ("Class action lawyers ... are their own clients in the sense that their fiduciary responsibilities to class members are what they determine them to be in the absence of court supervision and scrutiny"); Sande Buhai, "Lawyers as Fiduciaries" (2008-09) 53 St.Louis U.L.J. 553 at 555 ("Agency arises in relationships between client and attorney, employer and employee, partnership and general partner, and corporation and officer, among other contexts"). Also see R. v. McNeil, [2002] 3 S.C.R. 631 (S.C.C.) (which states that a lawyer has a fiduciary duty to his or her client, including a duty of loyalty). 
be carried out in a manner that advances the interests of the class. ${ }^{{ }^{116}}$ First, they must communicate the settlement offer to class representatives and to their clients - the class members. ${ }^{177}$ Second, they must protect the interests of the class as a whole, "even in circumstances where the class representatives take a position that counsel considers contrary to the interests of absent class members." ${ }^{178}$ Third, they must fulfill the "duty of candor" they owe to the court to disclose all information relevant to the fairness determination. ${ }^{179}$

Moreover, class counsel must make "full and frank disclosure" of "all of the available information that has some bearing on the issues, whether favourable or unfavourable," in a "manner that is not misleading or even potentially misleading." ${ }^{\prime 180}$ When class counsel fail to act in the best interests of the best class as a whole, courts can intervene and remove them from the class action. ${ }^{181}$

Accordingly, judges have a great responsibility and related discretionary powers at the class action review stage. While the judge's role of protector of absent class members should remain, I believe that this role can be better defined to attenuate the pressure felt on the "firing line," and best guarantee fairness of process and outcome for all those concerned by the class action settlements.

\section{PROPOSAL OF A REVISED ROLE FOR JUDGES REVIEWING CLASS ACTION SETTLEMENTS}

Attempting to revisit the judge's institutional role in class settlement review from how it has been described in the last few decades by North American case law and doctrine is a great challenge. Three preliminary remarks are mandated.

As a first remark, I want to underscore the fact that the judge's role could arguably vary - even very slightly - at each of the different stages of the review and approval of a proposed class action, depending on the objectives of each of the stages. At the settlement negotiation stage, the judge - if involved at all - would be a settlement facilitator, encouraging the parties to conclude the long-awaited settlement, to end the litigation and save expense and time. At the preliminary fairness hearing, the judge would carefully examine the settlement, weed out potential problem areas, point out and debate "red flags" or "hot buttons," ask questions, be inquisitive, and generally act as advocate for the class. At the final fairness hearing, the judge would thoroughly analyze the final proposal to settle, hear the final representations by the lawyers, hear objectors, and decide in a more adversarial stance. At the settlement implementation/administration stage, the judge would become an administrator or manager, ensuring the proper, fair outcome of the settlement. However, I have chosen to focus my proposal of a revised role to the two-stage settlement hearing process, since it is the process

176 Caputo v. Imperial Tobacco (2005), 74 O.R. (3d) 728 (S.C.J.) at para. 41.

177 See e.g. Kincade v. Gen. Tire \& Rubber Co., 635 F.2d. 501 at 508 ( $5^{\text {th }}$ Cir. 1981) ("the client in a class action consists of numerous unnamed class members as well as the class representative.")

178 Manual, supra note 28 at para. 21.641. Also see Lau v. Bayview Landmark Inc., [2004] O.J. No. 2788.

179 Manual, ibid.

180 McCarthy, supra note 99.

181 Richard v. British Columbia, 284 D.L.R. (4 $\left.4^{\text {th }}\right) 481$, at para. 41. 
when all aspects of the adversarial system that bear most directly on the judge's role are found.

As a second remark, my proposal does not - and cannot - properly consider the subjective variables that influence one's involvement - judicial or other - in a case. Variables such as one's personal temperament and abilities, the class action case and settlement's importance for the public, the efficacy of parties and counsel in presenting their case, etc. ${ }^{182}$

My third and last remark relates to a citation by one of the instigators of the American class action suit, Adolf Homburger, who more than thirty five years ago wrote about the role of the class action judge, outlining his most important responsibilities:

The most distinctive feature of class litigation [...] may be the uncommonly active role which the judge must play in the control and supervision of the proceedings. The public interest in the prosecution of a class action is far greater than in ordinary civil litigation. It is the court's function to protect that interest as well as the interests of the absent members of the class. The successful management of a class action, therefore, requires a procedure that leans more toward court-prosecution than ordinarily is the case in the American system. ${ }^{183}$

This extract contains key elements which directly relate to my suggested reviewing judge's role. I push Homburger's statement one step further to adapt it to the new class action reality of out-of court settlements.

Hence, in my view, reviewing judges should (1) maintain a steadily "active" judicial role in class proceedings; (2) seek to protect the interests of not only class members (particularly absent ones), but also those of the defendants and the public; (3) court-prosecute the class action settlement consistently with the inquisitorial tradition, rather than properly "case manage" it, and be a "searcher of solutions" when settlements are achieved and are asked to be approved to be made effective, in line with a more conciliatory approach to adjudication.

\section{A. The Active and Involved Judge}

The new class action reality is that most class actions settle. "[P]laintiffs and defendants come to court holding hands," 184 and courts are asked to scrutinize the parties' proposed settlement. Whereas judges used to rely on the parties to frame disputes and on legal standards to help resolve them, recently "overcrowded dockets and overzealous litigants have led judges away from this passive role." ${ }^{185}$ Rather than sit back and wait for the parties to frame legal disputes,

182 See e.g. Brooks, supra note 54 at 89.

183 Adolf Homburger, "Private Suits in the Public Interest in the United States of America" (19734) 23 Buff. L. Rev. 343 at 349.

184 Erichson, supra note 76 at 1985.

185 Jonathan T. Molot, "An Old Judicial Role for a New Litigation Era” (2003) 113:1 Yale L. J. 27 at 29. 
judges have begun taking a more active role. In class action cases, and their out of court resolution, they have also embraced this new role. ${ }^{186}$ Indeed, this role allows them to better protect the interests of absent class members and balance these interests with those of the class representative, of other members of the class and of the defendant.

Certain authors have spoken in favour of settlement and argued that judges must be active and involved in achieving peace for the parties, in the form of settlement. They argue that parties benefit if judges broach the issue of settlement early and often. ${ }^{187}$ Others have argued that judges involved in fostering settlements must take on an active role to contribute effectively to the settlement dynamic:

[T] he judge who is likely to contribute the most to the settlement dynamic is active rather than passive, analytical rather than emotional or coercive, learns the facts and law involved in the dispute instead of relying on superficial formulas or simplistic promises, and, after listening and learning with an open mind, offers explicit assessments of parties' positions and specific suggestions for ways to reach solutions [...] $[T]$ he judiciary's status and unique perspective converge to create a special potential for assisting in this sensitive business, but $[\ldots]$ this potential can be realized only by judges who, first, do their homework, then muster the courage to express their views and the self-control to do so tactfully. ${ }^{188}$

Whether the greater involvement of judges in fostering or achieving settlement is per se a positive development remains unclear and is another topic altogether.

In the class action context, judges are naturally led to be more active and involved, due to the public interest nature of this kind of litigation, and to its length and complexity. This natural propensity to be more involved and active is even greater at the stage of assessing the fairness of proposed settlements. Hence,

186 See e.g. on the new role: Pharmascience Inc. c. Option consommateurs, (2005) J.Q. no. 4770 (C.A.), at paras. 30 and 39 ("Within the mechanism of filtering and verification, the judge must, if the allegations of fact appear to give rise to the rights claimed, grant the motion and authorize the recourse; evidence will not be required in all cases...[T] $]$ he amendment to Article 1002 C.C.P. fits perfectly in the new environment created by the reform... which increases the level of intervention by the Court in the management of the proceeding in order to assist in bringing it to the essential step of the hearing on the merits...”). Similarly, in the U.S., the Manual for Complex Litigation has also steadily encouraged more active pretrial involvement by the trial judge in the development of the case; see Manual, supra note 28.

187 Marjorie O. Rendell, "What is the Role of the Judge in Our Litigious Society?" (1995) 40 Vill. L. Rev. 1115 at 1121 . Certain authors have formally spoken against settlement, arguing that it typically results in the litigants "leaving justice undone." See e.g. Owen Fiss, "Against Settlement" (1984) 93 Yale L. J. 1073 at 1085.

188 Thomas D. Lambros, “The Federal Rules of Civil Procedure: A New Adversarial Model for a New Era” (1989) 50 U. Pitt. L. Rev. 789 at 797 (quoting United States Magistrate Judge Wayne Brazil in Wayne Brazil, Settling Civil Suits (1985)). Also see Thomas D. Lambros, "The Judge's Role in Fostering Voluntary Settlements" (1984) 29 Vill. L. Rev. 1363. 
at that stage, judges should actively address and discuss the merits of the case, the extent of the injury at stake, and the elements each party has relinquished in the settlement negotiation process. They should also actively engage in ascertaining the substantive elements of fairness regarding the proposed settlement.

\section{B. The Judge as Protector of the Interests of Absent Class Members, Representatives, Defendants and the Public}

Class action judges have a responsibility to protect absent class action members, which translates into a fiduciary duty toward these members in the common law systems. In civil law systems such as Quebec, the common law concept of fiduciary duty or responsibility has no equivalent. ${ }^{189}$ Since the civil law concept of mandate does not apply to the relationship between the judge and the parties to a civil action, courts have referred to the judge as a protector of absent class action members. ${ }^{190}$ In this paper, I argue in favour of an enlarged duty of protection for reviewing judges, applicable primarily to absent class members, but also to the defendants and to the public.

First and foremost, the common law characterization of the judge as fiduciary of absent class members is not coherent with the traditional common law of agency. Indeed, the common law provides that "fiduciary relationships form where one party ('the fiduciary') acts on behalf of another party ('the beneficiary') while exercising discretion with respect to a critical resource." ${ }^{191}$ As explained by Professor Brummer:

[...] the description of the judge as a fiduciary is incongruous with basic principal-agent relationships usually indicative of such duties. Judges are not agents of plaintiffs, traditionally conceived. There is neither a contract nor a pledge of loyalty to plaintiffs; if anything, they act on behalf of the state and larger civil society. ${ }^{12}$

Another incongruity with the reference to fiduciary law notions in class action theory is the fact that the alleged fiduciary's responsibilities do not relate well into the judge's role as finder of the truth. Indeed, acting as a fiduciary necessarily involves choosing to take sides with the beneficiary. However, the judge's responsibility as truth-finder requires that he or she remain neutral at all times, without taking sides, a role more consistent with a duty of protection.

When parties agree on a class action settlement, they agree that it is fair to

189 Supermarché A.R.G. Inc. v. Provigo Distribution Inc., [1995] R.J.Q. 464 (C.S.), at $492-93$ and 504-05.

190 Pierre-Claude Lafond, Le recours collectif, le rôle du juge et sa conception de la justice - Impact et évolution (Cowansville: Yvon Blais, 2006) at $44 \mathrm{ff}$.

191 Brummer, supra note 157 at 1064.

192 Ibid. The attribution of a fiduciary duty to the reviewing judge has also been criticized by Professor Samuel Issacharoff: "in no other context do we find courts entering binding decrees with such a complete lack of access to quality information and so completely dependent on the parties who have the most to gain from favorable court action." See Samuel Issacharoff, "Class Action Conflicts" (1997) 30 U.C. Davis L. Rev. 805 at 808. 
each of their interests in each of their respective individual regard. Settlement fairness is then highly subjective. When judges evaluate settlement fairness, they balance the rights and interests of all the proponents. The conception of settlement fairness is much more objective. To best preserve objectivity at that stage, the judge should remain neutral and conciliatory as it protects the interests of absent class members.

The nature of the class action is to involve judgments against parties who are not before the court. Hence, when judges are asked to review a proposed class action settlement, the context naturally requires that they protect the rights of absent class members who are more vulnerable to ensure the respect of their interests. But class members are already protected by class counsel and representatives, whom, at common law, are their fiduciaries. Hence, reviewing judges should seek to protect absent class members by closely monitoring adequate representation and ensuring that the outcome will promote the respect of these members' interests and of class action goals.

Furthermore, judges should recognize, ascertain and protect the interests of the other class action actors and their need to obtain a fair settlement. When red flags are raised suggesting collusion or improper reasons for settlement, the protection of the defendant's interest should justify the exercise of increased judicial scrutiny. In fact, fair settlements benefit plaintiffs, defendants and society at large. Fairness will lead to the greater trust and confidence of taxpayers in the justice system. Hence, the public's interest in a fair settlement should be considered, notably through the respect of the class action objectives of deterrence and behavior modification.

One great example of a class action settlement which was approved upon consideration of the latter class action objectives was the Canadian Vitapharm settlement of an action alleging a conspiracy about the price of vitamins. ${ }^{193}$ That settlement provided that the defendants would contribute $\$ 102,782$, and that the end consumers of vitamins, who benefited from a cy près distribution, would not receive individual awards. Hence, this was a settlement where the outcome of the class proceedings had modest effect on class members, whereas the representative plaintiff and class counsel were at considerable risk in their endeavor to file the case, but where access to justice was promoted, and deterrence and behavioral modification of faulty defendants likely.

\section{The Inquisitorial and Conciliatory Judge}

In this paper, I have argued that the class action settlement context cannot guarantee fairness of process and outcomes when civil judges act in conformity with their traditionally adversarial role. Adversarial judges assume that the truth will emerge from the confrontation of opposing positions, while inquisitorial judges explore and sift through the evidence, not with a view to ascertain what evidence should be heard to "generally understand the case," but rather with a view to require the necessary evidence to "reach a justifiable decision" [emphasis added]. ${ }^{194}$ Accordingly, these judges are preoccupied with the search for the

193 Vitapharm supra note 101.

194 Geoffrey C. Hazard, Jr., "Discovery and the Role of the Judge in Civil Law Jurisdictions" 
"truth" and what is "just:"195 a responsibility lawyers cannot impede upon.

In the peculiar context of class action settlement review, where settlement parties are more vulnerable and their rights more fragile, reviewing judges should be principally preoccupied with finding the truth and what is "just" about the settlement. They should assume that the truth will arise from a thorough review of the relevant evidence in light of what they believe are the true interests and advantages of the settlement to class action members. To find the "truth," judges should become closely involved in defining the legal and factual issues, and verifying that they are addressed adequately in the settlement agreement. They should never rely entirely on the lawyers to adequately gather and interpret the evidence. Class action representatives should be asked to explain why they agreed to the proposed settlement. Arguments from objectors and attorneys on file should be welcomed and carefully evaluated. This more "paternalistic," activist and outspoken judicial role would certainly, in my view, help preserve the rights of absent class members, and the respect of their interests. ${ }^{196}$

Recently in 2006, UCLA Professor of Law, William Rubenstein published an article about the role of the judge at the fairness hearing stage, advocating the use of a combined adversarial and regulatory approach. ${ }^{197}$ In it, he rejects the inquisitorial mode because he believes American judges are not "particularly good at undertaking or overseeing factual investigations" of the proposed settlement, and not "conceptualized as factual investigators." 198 More specifically, he believes that judges are well equipped to evaluate substantive law questions, presented in an adversarial fashion, but that they, in essence, cannot investigate. In support of his proposition, he argues that judges have no formal training in "fact gathering," that they do not "possess the tools of the investigatory trade," and that since they are not specialized in class actions, they do not "know what it was they were looking for." ${ }^{199}$ In addition, he notes that these judges are "situated within an institutional framework that expects them not to perform this function." 200

This approach is too simplistic and generalized. It suggests that class action judges, who before becoming judges generally have many years of experience practicing law, cannot ask questions, raise issues, and review documents. Furthermore, it presumes that they are not knowledgeable about or comfortable with class action litigation, when that kind of litigation has become incredibly popular in North American courts, leading to the creation of class action divisions in most courthouses throughout North America.

(1997-98) 73 Notre Dame L. Rev. 1017 at 1022. Also see, e.g., See Carrie Menkel-Meadow, "The Trouble with the Adversary System in a Postmodern, Multicultural World" (1996-7) 38 Wm. \& Mary L. Rev. 5 (who argues in favour of rethinking the goals the American legal system should serve and the methods used to achieve those goals - more precisely, she is arguing against the adversary system).

195 See e.g. Frankel, supra note 56.

196 See Kotz, supra note 60 at 41.

197 William B. Rubenstein, "The Fairness Hearing: Adversarial and Regulatory Approaches" (2005-06) 53 UCLA L. Rev. 1435.

$198 \mathrm{Ibid}$. at 1472 .

199 Ibid. at 1473-4.

$200 \mathrm{Ibid}$. at 1474. 
The approach also wrongly assumes that because the civil justice system does not expect judges to ask questions and act inquisitorially, they should not do so. Acting inquisitorially does not necessarily require conducting an additional extensive inquiry into the facts. It requires sifting through the evidence, absorbing oneself in it, and asking questions - aloud or not. These tasks can properly be effectuated by the judge. And, in any event, when a judge acquires full knowledge and understanding of his case, he or she "knows what to look for," and what questions must be asked.

The decision to approve or reject a proposed class action settlement requires a certain amount and degree of "judicially initiated inquiry." ${ }^{201}$ But the role of the judge assessing and approving class action settlements is distinguishable from his role managing class action litigation. Indeed, case management is not required at the settlement stage, as the settling parties have already organized their case and presented their "contract to settle." Furthermore, managerialism should be limited because it creates a "potential for arbitrariness," which must generally be absent from the class settlement context. ${ }^{202}$

In the end, to reach fairness of process and outcome in class action settlements, judges should be proactive and creative in their inquisitorial assessment of proposed class action settlements. They should also be conciliatory, participating in a more flexible and creative search for solutions regarding the proposed settlement, always seeking to find the truth (and what is "just") about the proposed agreement. Finally, judges should assess and respect the interests and rights of absent class members, while also considering the interests of the defendants and of the public especially when red flags are raised about the proposed settlement.

\section{CONCLUSION}

In this paper, I have suggested a revised role for judges ascertaining class action settlement fairness, in light of the face of modern civil justice. In doing so, I have prioritized a judicial model that reflects the nature and values of society, and is responsive to existing legal practice and procedural culture.

In my view, reviewing judges should maintain an active role, with a largely discretionary approach to proposed class action settlements. They should safeguard the interests of absent class members by acting as their protectors rather than fiduciaries. In carrying out their role of protector, they should principally monitor adequate representation by class representatives and counsel. Judges should deny proposed settlements that concern class members who are not adequately represented. In the case of inadequate representation, these judges should only accept to review the proposed settlement de novo if representation is corrected.

201 Rowe, supra note 39 at 211.

202 Elliott, "Managerial Judging," supra note 41 at 317 (“[...] when judges make legaldecisions, the parties have an opportunity to marshal arguments based on an established body of principles, judges are required to state reasons to justify their decisions, and appellate review is available. None of these safeguards is available when judges make managerial decisions. [...] discretionary managerial decisions may influence the outcome of litigation in ways that are arbitrary because judges act without the procedural safeguards that accompany decisions on the merits."). 
Additionally, judges should categorically deny proposed settlements that are not wholly in the class members' best interests.

I have also argued that the defendants' interests should be considered by the courts where there are red flags or hot buttons suggesting abuse of process, or where there is public interest in having class action settlements approved as a deterrence or for behavioural modification objectives.

Finally, I have argued that judges should act inquisitorially at the settlement review stage, requiring enough evidence to reach a justifiable decision, and become personally involved with scrutinizing the settlement agreement, exploring and questioning the evidence, interviewing witnesses if required. 